Extrême-Orient Extrême-Occident

35 | 2013

Les astres et le destin. Astrologie et divination en Asie orientale

\title{
By the Power of Eternal Heaven: The Meaning of Tenggeri to the Government of the Pre-Buddhist Mongols
}

Par la force du Ciel éternel : la signification de Tenggeri pour le gouvernement chez les Mongols pré-bouddhistes

\section{Brian Baumann}

\section{OpenEdition}

\section{Journals}

\section{Electronic version}

URL: http://journals.openedition.org/extremeorient/290

DOI: $10.4000 /$ extremeorient.290

ISSN: 2108-7105

\section{Publisher}

Presses universitaires de Vincennes

\section{Printed version}

Date of publication: 1 May 2013

Number of pages: $233-284$

ISBN: 978-2-84292-367-9

ISSN: 0754-5010

\section{Electronic reference}

Brian Baumann, « By the Power of Eternal Heaven: The Meaning of Tenggeri to the Government of the Pre-Buddhist Mongols », Extrême-Orient Extrême-Occident [Online], 35 | 2013, Online since 01 May 2016 connection on 20 April 2019. URL : http://journals.openedition.org/extremeorient/290; DOI : 10.4000/ extremeorient.290 


\title{
By the Power of Eternal Heaven: The Meaning of Tenggeri to the Government of the Pre-Buddhist Mongols
}

\author{
Brian Baumann
}

In the days of the Mongol Empire edicts were prefaced with the phrase möngke tngri-yin kü̈̌̈̈n-dür "by the power of eternal heaven." One can imagine how this phrase struck fear and awe into those who encountered it. It reflected symbolically the potency of the Mongolian khans and reminded all of the power and ruthlessness of their armies. As a symbol of earthly power what could be more evocative than the omnipresent sky? What could be more ominous and foreboding?

Today, the fearsome, roving armies are no more. Even so, first-time travelers in the Mongolian countryside are often left awestruck by the sky and especially by the sky at night. Here in the dry, clear air where the land is dark, the stars appear more dazzling, numerous, lower to the ground, and brighter, than they do in urban settings. Standing in its midst, innately we feel the power of heaven as it looms above us. But what is this power exactly?

Our purpose in this essay is to pursue the question of what "the power of heaven" means to the Mongols in the early years of their empire. We are not the first to do so. Nor is it the most thorough. ${ }^{1}$ The uniqueness and value of the essay we submit is in its approach to the problem. We address the question of heaven in a scientific way. That is, we do not go about gathering up all the references to heaven in the sources and then interpret them according to what we think. Nor do we simply parrot back what the sources tell us for our readers to interpret on their own. These straightforward and standard methods have been tried but leave us wanting for two important reasons: first, modern perceptions of heaven are not necessarily the same as those of the 13th century Mongols. Second, the rhetoric of heaven in the sources does not for some reason lend itself to literal interpretation. Rather, then, our method is to study the sources in light

1. See de Rachewiltz (2007); I would like to thank Prof. de Rachewiltz for making his article known to me. See also Bira (2004); Beffa (1993); and Fletcher (1986: 30-32). 
of the first principles of science. We want to establish aspects of heaven that are first, universal, just as true today as they were during the Mongol Empire, and, importantly, that reflect science prevalent at the time. In doing so we can be much more confident that, apart from whatever else heaven might involve, what we understand about the power of heaven in the Mongol Empire is historically valid.

How we treat these first principles is dictated by the constraints of our medium. Though our discussion might be as brief or lengthy as we choose, we hope that it neither leaves readers lacking essential information nor taxes them unduly. Should our discussion of first principles not suffice herein, it is to be noted that we have discussed these first principles before and will again in contexts that allow for more careful elaboration. ${ }^{2}$

\section{First Principles}

A basic power of heaven lies in its facility to provide orientation and order over chaos. This power is essential to government. One cannot rule without understanding and in some way harnessing the power of heaven to the benefit of one's people. Even as we sense heaven's majesty in some aesthetic way, for those left to navigate the open expanses of the earth, as those who travel the Mongolian steppe and Gobi Desert, the reality of the power of heaven makes its presence felt as a matter of dire consequence. For without a star to guide us a trackless earth is void. Because nature is in truth or apparently void, order depends upon fixing in space an arbitrary point of orientation. From that point of orientation, time and space can be meted out in conventional systems. ${ }^{3}$

When it comes to the observation of natural phenomena, time, irrespective of duration, concerns occasions or events. That is, systems of time derive their regularity from the observation of heavenly bodies. Yet, as there seems to be no exact interval between successive occurrences of celestial events, the rising of the sun, for instance, there appears to be an absolute distinction between the perception of time as an event and the perception of time as duration. ${ }^{4}$

Hosts of celestial systems have been used throughout history to derive order. We know the spheres of the sun and moon, the five visible "wandering stars" or planets, and the sphere of the fixed stars. We know ancient observers used their morning and evening risings and settings, their transits or culminations, and so on. They divided the stars into constellations and bands. We recall the Egyptian decan system, the Western and Chinese zodiacs, the Indian nakshatra

2. See Baumann, Divine Knowledge (2008) and Fearful Symmetry (forthcoming).

3. Baumann 2008: 35-41.

4. Baumann 2008: 42-59. 
system, and so on. The ancients used the celestial bodies to navigate, to count units of time, and to fix the seasons on earth. From year to year these seasons were forecasted in calendars.

Because over long duration the positions of celestial bodies lose their efficacy as signs of seasons on earth, from time to time systems would have to be adjusted. These adjustments, as in calculating an intercalary month, were sometimes made on a regular basis. Sometimes they were epochal.

In creating and adjusting celestial systems, sages relied on the firmament. Unwavering, the firmament is comprised of metaphysical but otherwise perceptible things: the celestial poles (especially the North Pole for those in the Northern Hemisphere), the celestial equator, the ecliptic and its tropics, the seasonal nodes marking the solstices and equinoxes, the four cardinal directions, the colures, the horizon, and so on.

Order derived from observable celestial phenomena depends on the location of the observer. From different locations observable phenomena differ. With latitude observable stars and gnomon shadow lengths differ.

Here it is important to note that given this relativity, order to the universe was known to be topocentric. That is, the center of the universe was taken to be a political center, Babylon for Babylonians, Jerusalem for Jews, Rome for Christians, Mecca for Muslims, and so on.

From a topical center, locations on earth were marked by stars relative to a fixed point in space. Geography was thus defined according to astral orientation. ${ }^{5}$ In this system the horizons that limited one's realm nest. By the stars, one can orient oneself. By the same stars one can orient one's domicile, one's town, one's region, one's nation, all nations, and the earth itself.

Celestial systems allow the observer to know what is seen and what is unseen. When a star culminates in the sky, one knows that its counterpart is in inferior culmination, unseen below the earth's horizon seemingly underneath the earth. One knows the position of the sun by the position of the moon. When one knows the relative positions of all the celestial bodies used to govern, from any one sign one knows when and where every other sign will occur. As events and knowledge thereof was marked by heavenly signs, to know the full scope of celestial systems was to possess what was considered to be "perfect knowledge." 6

5. Berggren and Jones 2000: 8 .

6. The concept of the all-knowing (Mong. qamu $\gamma$ medegči) makes for an important topos in Eurasian history. Originally a term deriving from celestial orientation, under the influence of soteriological movements, it comes to evolve into something more. In the New Testament Paul mocks the old notion when he says, "If I have... all knowledge... but have not love, I am nothing" (I Cor. 13.2). In terms of celestial orientation, the topos was often represented in terms of the relative position of the sun and likened to 
It was widely held that when celestial bodies are seen they were deemed to exist and said to be "alive," residing in heaven. When unseen they no longer exist and were considered to be "dead," residing in hell from whence they are resurrected and return to life in heaven. Though we tend to associate it solely with death and punishment after death, hell, we must remember, is first and foremost a scientific term. It refers to that in heaven unseen or hidden. ${ }^{7}$ When the sun is up and the stars are shrouded by daylight, the sun is in heaven, the stars, in hell, and vice versa. When the celestial bodies are hidden by clouds, they reside in hell; and so on. Thus, for instance, in the Turkish Kül Tigin Inscription, when we read that east is defined by sunrise; south by noon; west by sunset; and north by midnight, north is being defined in Turkish tradition by the position of the sun in hell. ${ }^{8}$

In a universe so wrought, order changes from place to place, realm to realm. There are many worlds and just as many heavens. Nations did not all have the same stars to work with; they did not share the same seasons; nor would they necessarily mark a given season, the season for sowing, for instance, in the same way. By the same token, ancient peoples did not live in their own respective vacuums either, but, rather, shared much of the same sky. Moreover they had to rely on a shared version of the sky in their interactions with each other. ${ }^{9}$

Government derived from the observation of celestial bodies imparts a symmetrical relationship to heaven and earth. Events on earth are tied to their season in heaven. The configuration of heaven reflects the order on earth. This symmetry is easy enough to understand, but its implications are less so.

Import to realize is that the symmetry between heaven and earth needs be expressed through figurative language whereby physical action plays out through allegory. Allegory is precisely that which reflects an event's simultaneous tie to heaven and earth. The fixed background that rules the movements of the stars was known figuratively as "the firmament." The firmament was likened to a dome, vault, cup, or cauldron and said to be made of stone, lapis, crystal, gold, silver, or the like. The celestial poles were likened to a "pole." Peoples marked the celestial North Pole with a star. That star marks the pole constantly, that is, every day, and was likened to a peg, spike, or nail. A line from the celestial pole to the point of observation forms an axis likened to the axle of a cart, or to a staff

an "all-seeing eye." The trope was a commonplace, known in Egypt, throughout the Near East, in India, Central Asia, and China. We will discuss the notion in terms of the four directions infra.

7. See the OED.

8. Tekin 1968: 261.

9. To interact in Inner Asia, Turks and Mongols relied on Chinese celestial systems, in particular the Twelve Animal Cycle. See Bazin (1991: 117-227). 
or tree. The heavens turn round this axis like wheels of a cart or a mill wheel grinding. The seasonal nodes, that is, the solstices and equinoxes, are fixed in the firmament. They come to be "guarded" by stars or asterisms. The seasonal nodes make up the foundation of heaven and are likened to cornerstones, mountains, or other geographic features. The seasonal nodes are linked through colures. The solstitial and equinoctial colures intersect at right angles at the celestial North Pole and divide the heavens into four equal spheres. These four spheres when reflected onto the earth in geography are known as islands, continents, or four separate oceans. The colures form the brace-work of the heavenly vault and are oft likened to pillars of stone or sycamore or cedar trees. The ecliptic is likened to the meandering course of a river. The horizon that limits one's realm is likened to a world-encompassing ocean.

In symmetry between heaven and earth every term has a hidden meaning. It has a heavenly antecedent and an earthly antecedent. For instance, a place name such as Ethiopia refers not only to a location on earth but to a point in space by which that location is known. As heaven takes precedence over earth, the astral denotation has priority over the mundane denotation. A term such as "Ethiopia" refers principally to a point in space and only secondarily refers to an earthly location. Thus as given by the relativity of orientation, it is possible for each individual realm to have its own "Ethiopia." 10

The stars assume the guise of virtually everything under the sun. At the same time, they are, individually and in systems, oft likened to animals. ${ }^{11}$

The full embrace of everything contained within the heavenly vault was widely conceived of as a tightly woven matrix. This matrix filled the void in nature with an all-embracing, fatal order. It served as the backdrop to all events on earth. It was colored by the times for every purpose. It governed the government on earth and was made in and reflected the government's image. Important to note is that in signifying a time for every purpose, heaven is amoral. It reflects both good and ill. And its auspices, awesome and eternal, inspire fear.

For nations of Eurasia, the literature of heavenly allegory constitutes fundamentally the language of order over chaos. It is central to government and the language of science and religion. The disciplines of learning, be they geography, music, or what have you, derive from heavenly allegory like spokes

10. In the Odyssey (I.22-25) the term "Ethiopia," meaning "Land of burnt faces," describes a race of people of swarthy complexion. At the same time it represents an astronomical phenomenon in that it marks the Southern limits of the known world and thus divides the world into Eastern and Western Hemispheres. For "Ethiopia" as a region of the sky, see also "Andromeda" and "Perseus" in Allen (1963).

11. For a survey of some of the various tropes by which celestial phenomena were known, see Allen (1963: passim). 
from the hub of a wheel. One who governs does so by way of heaven. The emperor is said to possess heaven's favor. He who possesses heaven's favor relies on heaven to control and shape the destinies of others.

\section{Beyond the Dome of Heaven}

Government based on reliance on the observable heavens, characterized as it is by symmetry between heaven and earth, relativity and subjectivity, allegory and esotericism, contradictory systems and much complexity, has its limitations. One overarching set of heavenly signs does not effectively govern vast tracts of earth. Importantly, ruling the world by reliance on stars observable to one in the Northern Hemisphere leaves the Southern Hemisphere ungovernable. (Peoples were left to describe the Southern Hemisphere as a chaotic expanse of water).

In history the idea arose of governing the whole world, that is, the entire sphere of the Earth, under one system. ${ }^{12}$ To overcome the fact that observation is relative to a fixed location, this idea depended on mathematical abstraction. Time and space were rationalized according to mean averages. These measures do not perfectly reflect natural phenomena but neither do they vary. Whereas in nature the duration of an hour is variable from day to day and place to place, as a mean average, an hour remains constant wherever one goes. Thus we speak of "mean time" versus "true time." ${ }^{13}$ In this way the "zodiac" may refer to a band of constellations along the ecliptic but likewise to the rationalization of space into twelve "houses" each of 30 degrees. ${ }^{14}$

We find the reliance on numerical systems capable of predicting the positions and movements of celestial bodies develop in ancient Mesopotamia. These mathematical systems transcend the power of mere observation for ordering the heavens and ruling the earth. O. Neugebauer rightly recognizes the significance of this development when he distinguishes the treatment of celestial phenomena in terms of mathematics from other aspects of astral science. He dubs this computational approach "astronomy." 15

This distinction between observation and computation is important to emphasize. Although the terms are often conflated, celestial orientation and mathematical "astronomy" make for two separate approaches to reckoning.

12. See Geus'brief discussion of the history of the oikoumene (2011: 554) in his review of Roller (2009).

13. For the distinction between "true" and "mean" time, see for instance al-Biruni's discussion of the beginning of the Hebrew month in his Chronology (Sachau 1879: 68). See also Baumann (2008: 42).

14. For the history of the zodiac, see Neugebauer (168: 187).

15. Neugebauer 1945: 2. 
Although only certain civilizations relied on mathematical astronomy, peoples in general relied on observation systems carried out by means of a gnomon. So too we must distinguish from celestial orientation proper divination methods that derive from (often abstract) representations of the stars. Although it too conflates, that which we frequently dub "astrology" has a definable history. ${ }^{16}$ Conversely, although conventional systems of celestial orientation are amenable to history to some degree, the science itself is not.

To imagine governing the sphere of the earth with one system entails seeing the world in an entirely different mode. By abstracting time and space away from observation the subjective world relative to one's point of observation becomes an objective world fixed in space irrespective of any one observer. In this transformation the center of the earth goes from an arbitrary topical center within a given realm to the very core of the earth itself. The worldview thus shifts from that which is "topocentric" to the "geocentric."

It is worth noting that a casualty of this change in worldview is hell. Hell, we remember, refers to that in heaven which is "unseen" or "hidden." The concept implies a subjective, topocentric worldview. From an objective, geocentric worldview whereby we conceive of the existence of the entire sphere of the earth in the midst of the heavens irrespective of the view of any one observer, nothing is unseen or hidden. Hell ceases to exist. Champion of the objective, geocentric worldview, Ptolemy dismisses hell in his Syntaxis (1.3.12), when he writes: "But to suppose that [the stars] are kindled as they rise out of the earth and are extinguished again as they fall to earth is a completely absurd hypothesis." ${ }^{17}$

In keeping with the objective mode of viewing nature, the rhetoric of knowledge changes as well. The idea of governing the entire sphere of the earth in one system engendered a faith that through close observation and numerical computation perfect constants could be found that would eliminate the irrational remainders that make any one phenomenon incommensurate with any other. The successful determination of celestial phenomena would bring everlasting order. It was a matter of faith in determinism that the apparent contradictions that exist in Nature's logos could be coherently explained. In this faith in determinism, the rhetoric of knowledge shifts from allegory to explanation.

Allegory and explanation, we must realize, are antithetical modes of discourse. As modes of scientific discourse, they represent two distinctly different worldviews. It is not that science from the subjective, observationbased, topocentric worldview could or could not explain phenomena. In relying on allegory to represent symmetry between heaven and earth, this mode of

16. Baumann 2008: 16-24.

17. Toomer 1998: 39 . 
scientific discourse simply does not explain. In this allegory does not show a poor understanding of nature. It shows, rather, (by and large) a perfect (or true) understanding of nature.

Explanation, on the other hand, tends to be imperfect. In shifting to an objective, explanation-based rhetoric, in order to avoid obvious contradictions, peoples had to settle on conventions, simplifications, and abstract and imperfect definitions of terms. For instance, although in truth or apparently a semblance of order can be derived from any point, in order to explain an objectively determinate universe a one center had to be chosen. Ultimately most would settle on the core of the earth as the center of the universe. Some peoples, however, preferred the sun. ${ }^{18}$ Likewise the earth appears to be ever-moving and yet at the same time still. ${ }^{19}$ To render each concept in allegory, whether we understand the world in stillness as a mountain or in motion as a turning wheel, presents no problem whatsoever. However, in order to represent the world through explanation peoples were forced to choose one state or the other. ${ }^{20}$ In the same way, any given celestial event, be it the day, month, year or what have you, can be defined in any number of discrete ways. The day, for instance, can be defined relative to the sun, moon, or stars, from noon, midnight, sunrise, sunset, dawn, dusk, and so on. To represent the day without contradiction peoples simplified the concept into an imperfect abstraction of 24 hours duration..$^{21}$

If these imperfections may be seen as drawbacks, the objective, geocentric worldview has a tremendous upside in comparison with the subjective, topocentric view. Whereas the subjective, topocentric worldview, limited as it is to what one perceives through the senses, is relatively static, the faith-based, objective, geocentric worldview, on the other hand, is exceedingly dynamic. In striving for a singular, abiding, perfect world order, the objective, geocentric worldview pits the full power of the mind against the power of the feeble senses. Thus it employs logic, argument, dialectic, experiment, numerical computation, observation over long duration, technology, and so on in the effort to ever better rule the world. When it comes to practical knowledge, understanding

18. Barker and Ariew 1991: 2-5.

19. Zeno noted this paradox. See Baumann (2008: 93).

20. In the Āryabhațīya of Āryabhața, for instance, W. Clark notes a fascinating discrepancy. In Indian astronomy the earth is generally held to be stationary as the heavenly bodies revolve around it. However, in this text one stanza maintains that the stars are stationary and that the earth revolves on its axis. Then in the next stanza the roles are reversed. The earth is seen as stationary and the stars revolve around it (Āryabhața 1930: xiv).

21. Baumann 2008: 64-66. 
and predicting phenomena, the objective worldview quickly outmodes the subjective. ${ }^{22}$

Faith in an inherent order in nature and hope for a single system to govern it engendered political change as well. People envisioned one government to rule the earth. The propaganda of this new political movement led to a new conception of heaven and hell. In it the heavenly dome itself was transcended by a higher heaven. This higher heaven would be given by everlasting moral order. Here no dichotomy exists between good and evil. Only good is to be found. No error or sin is known. Life goes on in joyfulness, and death is no more. We will discuss this transcendence of the vault of heaven in more detail below.

Yet, it is important to remember that even though the vault of heaven comes to be transcended by a higher heaven, even though explanation gains preference over allegory as the rhetoric of science, and even though the dynamic faith-based system far outstrips the static observation-based system in terms of practical applications, the subjective, observation-based system and its heavenly vault retains its relevance in terms of simple, basic science. This in part is because to this very day we have not found the constants that explain natural phenomena without contradiction. It continues to be allegory that truly and perfectly renders "the thing itself." At any rate, the rhetoric of heavenly allegory was maintained in literature and as a means of political propaganda even among traditions that adopted the objective, geocentric worldview.

As it relates to how we understand heaven today, we note that the interplay between the rhetoric of allegory and explanation, true science and faith-based science, has characterized much of the history of Western Civilization. We see this interplay in the rise of Christianity out of 'pagan'tradition, in the rise of Protestantism out of the Reformation, in the re-emphasis on pagan tradition during the Renaissance, and so on. With the Enlightenment in the 18th century, however, renewed faith in determinism fosters an out and out rejection of allegory as the language of science. The heavenly vault is all but annihilated by Galileo's Solar System and Newton's Laws. In the perfection of Geography, the symmetry between heaven and earth comes to be all but forgotten. With the world mapped in full, there is now no point in resorting to relative orientation and celestial allegories such as the 'four oceans'or 'four continents'to describe it. Stemming from this cultural transformation, scholars of the Academy, firmly grounded in Enlightenment rhetoric, come to take the ancient allegories literally and write them off as imaginary.

22. In world history the triumph over the subjective, topocentric worldview is epitomized by the fall of Babylon. See, for instance, Isaiah 47.10-13. 
Approaching the 20th century, with the coming of modernity, this trend towards determinism only intensifies. During the Enlightenment, the Bible, which throughout Christian tradition has been reinterpreted over and over again according to the politics of the time, was again reinterpreted. ${ }^{23}$ Still, the Bible and the various churches, Catholic and Protestant, retained their authority in governing people's lives. With modernity, however, the biblical writings are treated in the same way as other "mythologies." Not only is the Bible taken literally, it too comes to be written off as imaginary, nonsense. The result of so doing has created a yawning chasm between "science" and "religion," "us" and "them". It makes a clean cut separating ourselves from the pre-Enlightenment past.

\section{The Misapprehension of Heaven}

Yet, although that which is taken for science is deemed the epitome of science, this, we must remember, makes for propaganda. Modern Science is actually a counter-science of the type the ancients employed to vanquish less potent governments ordered merely according to that which is given by feeble senses. Science, after all, concerns perception. But "Modern Science" intentionally ignores perception. The Western scientific method concerns not what any one person perceives to be true but, rather, the objective proof of what one perceives to be true. One might argue that it is this fundamental rejection of the primacy of science that gives "Modern Science" its tremendous potency. But making such an argument is not our purpose here. Nor by pointing out the paradox of "Modern Science" do we express our political views. Our point is merely that in seeing the scientific tradition of recent centuries as a watershed between all that had come before Western Civilization has undergone anything but a return to allegory as the language of science and government.

As a result of these political developments, a misapprehension of the science of the pre-Modern world abides as an almost universal characteristic of modern scholarship. It exists even, and often especially, among historians of science, who ought to know better. Although the problem is complex, in essence, the misapprehension of pre-Modern science comes from understanding pre-Modern science simply as an inferior form of our own tradition. In so doing we fail to recognize that pre-Modern science belongs to a distinctly different mode. When it comes to this incongruity, we assume that because in our tradition the role of science is to explain nature, pre-Modern science must function in the same way. To this end it appears to us that it does so very poorly. We forget that pre-Modern

23. See, for instance, Whiston (1755). 
tradition does not explain nature. It governs nature. It orders chaos. It does so through figurative language, allegory. Thus in equating pre-Modern science with our own tradition, we tend to take literally what in fact is figurative and write it off as imaginary. This bent towards literalism obscures traditional science and makes the rhetoric of the non-Modern world all but impossible to understand.

Specifically, this misapprehension of science and religion casts a pall over heaven, what it is, how it functions, and its history. For modern people the power of heaven has in many ways been lost. The inroads of civilization being pervasive as they are we seldom face head-on the void in nature. Artificial light makes the stars difficult to view. More than this, our semblance of time and space, standardized of system, has been abstracted away from observable phenomena. To us, the day, month, and year no longer appear to depend upon the positions of the sun, moon, and stars (though ultimately, of course, they do). Still, in English the word 'heaven' retains its empirical denotation. ${ }^{24}$ We are free to refer to it in this sense. In "Brothers in Arms" the artist Mark Knopfler does so when he sings:

Now the sun's gone to hell,

And the moon's riding high.

Let me bid you farewell,

Every man has to die. ${ }^{25}$

Yet ideologies and institutions - sacred and secular - bound by political struggle muddle our perception of heaven and its power. Christian churches de-emphasize empirical heaven and its allegories in favor of a literal interpretation of the Bible. Given the conflicting views of what heaven entails, scholars are wary to presuppose any empirical reality to heaven whatsoever. Yet, ironically, as a result of doing so, the empirical reality of heaven is left out of their discourse, and they too promote an abstract understanding of heaven. ${ }^{26}$ In elevating an abstract notion of heaven to the exclusion of its empirical reality, intellectuals often give

24. OED s.v. 'heaven'.

25. Knopfler 1985 .

26. Beffa (1993: 217-218) cautions that translating tenggeri as "heaven" leads to false associations with Judeo-Christian "God." Then Beffa distinguishes Mongolian tenggeri from Western "heaven" by suggesting that, as singular and plural cannot be determined in Mongolian, the term, based on references to 33 and 99 tngri-ner in later Buddhist sources, probably means "gods" in the plural. However, singular and plural can be and are differentiated in Mongolian, especially in the 13th century, when the language and a wealth of sources all tell us tenggeri is singular. References to 33 and 99 tngri-ner in later Buddhist sources are just that, later Buddhist sources. This is not to say the preBuddhist Mongols did not know of them. We simply have no evidence. Even so, it is not unlikely these gods have some antecedent in nature. More importantly, the discussion 
a false sense of religion as being based on nothing more than spirituality or that which is imaginary.

Though heaven was once the foundation of government on earth, it is no more. Though heaven was once known through multifarious systems, these systems by and large have been forgotten. Though aspects of heaven were known through allegory, we want to take these aspects literally. In the modern world heaven has been fragmented into parts. Today "heaven," "astronomy," and "astrology" are taken for three separate subjects belonging to three disparate disciplines. "Heaven," which can no longer be uniformly defined, we conceive of as belonging to Religion; "Astronomy" belongs to Physics; "Astrology," Anthropology. Not only do these subjects have little or nothing to do with each other, none are understood principally in terms of orientation; none is held to form the basis of government; and none is deemed essential to one's education.

The profound misapprehension of the science and religion and the commensurate misapprehension of heaven negatively influence how we understand the traditions of the peoples of the non-modern world and the heavens they relied on in government. In particular these misapprehensions have negatively influenced how we understand the pre-Buddhist Mongols and their tenggeri "heaven." In general terms, misapprehension has led to a tendency to view the pre-Buddhist Mongols as wholly alien of culture. Though it is admitted their tradition bears great affinity with that of the ancient Turks, the Mongols are held to be in their own way unique. A singularly primitive people, the Mongols were primitive not only in material culture but intellectually. They were simple-minded and superstitious. Nature weighed heavily upon them. In their failure to understand nature their natural response to what they experienced was one of fear. Though they lived on the open steppe and practiced animal husbandry, their primitive culture reflects a hoary antiquity when they lived in the forests of the taiga and subsisted as hunters and gatherers. In their barbarism occasionally they would take advantage of their skills on horseback and with a bow and arrow to raid their civilized neighbors. These raids, we are given to assume, were ad hoc. To mitigate their fear of nature they relied on shamans. These shamans, however, were nothing more than quacks. Their claims to secret knowledge masked more of the same ignorance and fear of nature. They maintained their grip on people's lives through the use of divination to give the weight of authority to random action and through the use of ecstatic trance to journey to imaginary worlds above and below. They practiced animism. Apart from the worship of animals they also practiced something we know as

shows that Beffa thinks of tenggeri primarily in terms of god or gods and not in terms of heaven proper, where the difference between singular and plural dissolves like snow. 
"Tenggerism." Their word tenggeri, written tngri, was not merely the sky but "heaven." With "religious and mystical overtones" we cannot pretend to know what it means. We equate it with "God." 27

From this perspective, the Mongols appear to have been unwitting observers to the rise of their own world empire. In an article dedicated to Ilkhanid patronage of astronomers, the eminent scholar George Saliba describes Hülegü's interest in astrology as one of naïve bemusement over the sophistry of its cunning Islamic sorcerers. "The position of astrology in Hülegü's mind was probably very simple," he says. ${ }^{28}$

But why would we assume so except for the deep-seated, longstanding stereotype of the Mongols as a simple people? After all, Hülegü relied on heaven every step of the way on his campaign from the Mongolian homeland to the heart of Baghdad. He relied on heaven for basic logistics, for the organization and discipline of the people under his protection, and for the sophisticated propaganda it would take to rule the subjects of his realm. ${ }^{29}$

The equally eminent scholar Nathan Sivin goes so far as to exclude the Mongols from their own world empire when in his many-ways masterful study of the Shoushili 授時曆 he describes the Yuan dynasty (1264-1368) calendar project as "The Chinese Astronomical Reform of 1280." ${ }^{30}$ As Sivin would have it, Qubilai Khan (r. 1260-1294), wise in the knowledge of his own limitations, sits idly by and lets his trusted advisor Liu Bingzhong 劉秉忠 (1216-1274) build an empire around him. In addition to the completion of the Shoushili calendar reform, Sivin has Liu Bingzhong single-handedly conceive of, propose, and lead, the organization of the government of China and the building of two great cities, Shangdu and Dadu. ${ }^{31}$ Here, as throughout his publications, Sivin goes out his way to promote the learning and culture of the Chinese people against stereotypes of barbarism, superstition, and ignorance fostered by apologists for the supremacy of the West. One might note that Sivin's polemics are less pertinent now that China has become the rising intellectual, cultural, and economic leader of the world. At any rate, in Granting the Seasons Sivin's apologies for Chinese learning at times come at the expense of the Mongols' and their learning.

27. Clauson 1964: 359 . We have constructed in this paragraph a straw man, to be taken for what it is worth. Specific criticisms will follow. Clauson (1964: $350 \mathrm{ff}$.) describes Turkish astral tradition in terms of evolution from ignorant, primitive beginings.

28. Saliba (2006: 362).

29. For Hülegü, see Thackston (1998: $471 \mathrm{ff}$.).

30. We quote the subtitle of his book.

31. Sivin (2009: 24, 153-156). 
Important to note, Sivin's mistake of agency comes not only at the expense of the Mongols but at the expense of the history of science and the humanities in general. It does so because it continues on in the framing of the history of science as the product of race, blithely forgetting that science, essentially, and certainly in the case of Chinese and Asian traditions, concerns the means to, and product of, governance. It is in the history of science's tradition of emphasis on race over government that puts good scholars such as Sivin on the defensive in the first place. The harm of this misguided approach to the history of science is grave. We would do well to stop it.

\section{Heaven}

We begin our study of the power of heaven among the pre-Buddhist Mongols by noting the primacy of heaven in their government. Pre-Buddhist Mongolian government (törii) is based on the auspices of heaven. As the Song dynasty envoys, Peng Daya and Su Ting, note, the Mongols all, from lord to commoner, speak of their reliance on heaven. ${ }^{32}$ In this reliance, there is no evidence whatsoever to assume that Mongolian tngri means anything beyond or other than heaven proper, that is, the totality of celestial systems culminating in what was described figuratively as the heavenly "vault" or "dome." Neither a single Mongolian source nor any foreign commentary makes reference to breaking through or otherwise transcending the dome of heaven in the way Buddhism, Christianity, Islam, and other like traditions do. We do not find the abstraction of heaven into a moral, everlasting realm where good prevails and evil, sin, and death are no more. Nor does the Mongols'heaven stand for common humanity, as that of the monotheistic traditions does. Likewise, the Mongols'heaven does not afford the same freedom and protection to all people of all nations.

It goes without saying that the Mongols reckoned with hell. Yet, there is no evidence to suggest they had assimilated the propaganda of Hell as a place of everlasting punishment. It is an open question whether they used the term tamu "hell," which derives from Sogdian by way of Uygur, to designate astral phenomena unseen or hidden. It is also an open question whether or to what extent that which is unseen in heaven was linked in some way with rites of death and/or forms of punishment.

Should the Mongols have relied on empirical heaven, they would not have been alone. The Chinese dynastic tradition deifies the power of empirical heaven over government. So too do the Turks. Indo-Iranians do the same. So too, peoples of the Near East. Though Christians and Buddhists transcend this power, they

32. Olbricht and Pinks (1980: 141). 
rely on empirical heaven just the same. Indeed one is hard pressed to find one tradition in pre-modern times where this is not the case. Pliny describes the deification of empirical heaven as a commonplace when in his Natural History (2.1) he says, "The world and this - whatever other name men have chosen to designate the sky whose vaulted roof encircles the universe, is fitly believed to be a deity." 33

Furthermore, there is every reason to believe Mongolian tenggeri does indeed refer to the empirical heaven of natural history. Sources tell us so outright. In the Secret History ( $\$ 254 \ln .10323$ ) regarding the tumultuous chaos and strife prior to the time of the birth of Chinggis Khan's son, Chaghadai, we read hodutai tenggeri horciju büle'e "the starry heavens were revolving." ${ }^{34}$ In the Chinese subject-glossaries of Mongolian language, the Zhiyuan yiyu 至元譯語 (13th c.), compiled during the reign of Qubilai (r. 1260-1294), and the Ming dynasty Hongwu (r. 1368-1398) era Huayi yiyu 華夷譯語 (1389), under the category of tenggeri fall aspects of empirical heaven. These include sun (nara), moon (sara), star (hodun), Ursa Major (dolō ebügen "seven old men”), the Pleiades (ülger $<$ Tu. ülker), the Milky Way (tngri-yin oyalar), air (kei), rain (qura), and so on. ${ }^{35}$

Epithets that describe the godly nature of tenggeri such as de'ere "above, supreme," möngke "eternal," and erketï "mighty" apply equally to the nature of empirical heaven. ${ }^{36}$ Empirical heaven is both above us and supreme in governing our lives. Its auspices are indeed eternal and mighty. What is more, these epithets make for commonplaces throughout Eurasia where again they refer to empirical heaven. In Hebrew tradition, for instance, in the Book of Enoch (72.1) the term hezabihomu "their tribes, nations" refers to the hierarchical grouping of stars. The term šeltānomu "their powers" refers to the power of heaven exercised by stars over the division of the year into its times, seasons. ${ }^{37}$

Likewise, in the functions attributed to tenggeri we see the functions of empirical heaven. As tenggeri is said to shape one's destiny (jaya'a $[n]$ ) and offer one protection (ihe'el $\sim$ ibegel), in ruling the seasons so too does the empirical heaven. ${ }^{38}$

33. Rackham 1949: 171. For Chinese tradition, see Schafer (1977). For the Turkic, see the Qutudqu bilig as discussed in Clauson (1964: 355-356). For Indo-Iranian tradition, see Darmesteter (1974: LVIII) who tells us that the god that establishes the laws in nature is heaven, the all-embracing sky. See also DDD (s.v. "Heaven").

34. de Racwiltz 1972: 150; 2006: 183.

35. Ligeti 1990: 259-262; Kara 1990: passim; Haenisch 1957: 9.

36. These attributes of heaven have been noted by de Rachewiltz (2007: 113ff.).

37. Black 1985: 393. See also Enoch 79.2 (Black 1985: 410-411). For a more general discussion of the concept in the Near East, see DDD (s.v. "Almighty").

38. See the discussion of "The Roles of Heaven" in de Rachewiltz (2007: 117-123). 
When we know how to look we see the natural basis to Mongolian tradition in more subtle ways as well. For instance, it is well known from accounts such as that of William of Rubruck that the Mongols strewed milk offerings to the four directions. ${ }^{39}$ Although today the cardinal directions stand alone in our minds as comprising a thing unto itself, in antiquity they were inextricably linked with the full sweep of heaven. As we have seen, the four directions were defined relative to the solstices and equinoxes, the stars that "guarded" them, the prime meridian, the colures, and all within the dome of heaven. In symmetry the dome of heaven came to reflect all earthly events. Thus, as was also often true of the sun, the four directions stood for the perfection of knowledge. In Chinese tradition, for instance, the character 十 shi "ten" represents the four directions and the center, that is, it represents the all, whole or perfect. The character $\pm s h i$ "gentleman, scholar" signifies one who possesses all knowledge. This pervasive scientific context strongly suggests that in making offerings to the four directions the Mongols acknowledge and revere the four directions for order over chaos and the totality of knowledge they afford. The ritual also strongly suggests that tenggeri, heaven itself, was known to them in these terms.

The natural history of heaven is also suggested in Mongolian tradition by its rhetoric of symmetry between heaven and earth. We see symmetry in the common refrain tngri qajar-a "in heaven and on earth." And we see it in allegorical passages throughout the Secret History of the Mongols. For instance, in Dei Sechen's auspicious dream a heavenly sign in the form of a white falcon approaches clutching both the sun and moon. In this passage the white falcon symbolizes heaven. Precisely how the white falcon does so requires elaboration beyond our scope. However, the context of the passage, concerning as it does the boy Temüjin and the girl Börte, makes it perfectly clear that the sun and moon represent the emperor and empress. ${ }^{40}$

The nature of symmetry between heaven and earth is further characterized by what constitutes its absence. The high-priest Teb Tenggeri's fall from heavenly grace comes through the breaking of his connection to heaven made manifest by the covering of the smoke-hole of his tent. The break from heaven results in his loss of earthly power and his eventual execution. ${ }^{41}$

Suggestive of its scientific function in signifying a time for every purpose, heaven to the Mongols is amoral. As John of Plano Carpini notes, the Mongols'heaven is "the giver of the good things of this world as well

39. Dawson (1955: 96).

40. de Rachewiltz (2006: 14).

41. de Rachewiltz (2006: 173). 
as the hardships." ${ }^{42}$ Likewise, in governing the times for every purpose the Mongols'heaven sanctions all successful outcomes. If there was a battle to be fought, it was won or lost depending on heaven's favor.

As victory or defeat in battle suggests, heaven's auspices are eternal (möngke) - but not exactly everlasting. The difference between everlasting and eternal is import to understand. We see the distinction in Lewis Carroll's rhyme Humpty Dumpty. Here an egg on a wall does not abide forever, but the breaking of the egg is eternal. ${ }^{43}$ In the difference between "everlasting" and "eternal" we have a distinction between that which belongs to time's duration and the moment of time itself. ${ }^{44}$ These two inevitably conflate, yet the perception of one tends to hold primacy over that of the other. Those who understand nature in terms of observation of phenomena are wont to emphasize the instantaneousness of time over time's duration and wont to emphasize the eternal over the everlasting as well. ${ }^{45}$ Emphasis on time as duration and on the everlasting comes through the abstraction of time. This emphasis on time as everlasting duration has a history in Zoroastrian Zurvanism, which in turn influences the soteriological movements and monotheistic faiths. Thus traditions in their propaganda referred to the notion of "everlasting life." 46 We do not want to draw any hard distinctions as to whether the term möngke refers to either the eternal or the everlasting. Rather, we observe that the notion of "everlasting life" appears not to be promoted in Mongolian sources. ${ }^{47}$ More importantly, we can say with certainty that the

42. Dawson (1955: 9)

43. Carroll (1946: 231).

44. For the significance of the distinction between instant and duration, see Baumann (2008: 42-59).

45. For insight into historical representations of eternity and everlasting and how they interrelate, see M. Clagett's study of Egyptial astral science. Here eternity is defined as the "eternal past." Once an egg is broken it will never be remade. Everlastingness, on the other hand, is defined as the "eternal future." The egg is broken, and it always will be (Clagett 1989: v.1, x, 369-370). The deity Shu is associated with eternity; Tefenet, everlastingness (Clagett 1989: v.1, 438). The day (when the sun is seen) is associated with eternity; the night (with the sun in hell), everlastingness (Clagett 1989: v.1, 462). The sun god, Amon-Re, is said to be "enduring in all things" (Clagett 1989: v.1, 556). Amon-Re is said to be the Lord of Eternity who makes Everlastingness (Clagett1989: v.1, 557). The Egyptian tradition offers but one example. A thorough study of question as it relates to Mongolian tradition is beyond our scope. Beffa (1993:218) rightly notes that the translation of möngke as "eternal" can be misleading.

46. For Zoroastrian Zurvanism, see Boyce (1982: 231-262). See also DDD (s.v. “Aion”).

47. An interesting scene between Chinggis Khan and his Daoist master, Changchun 長 春, gives some insight into this question. Changchun is famed among the Mongols as "Tängri Möngkä Kün" (lit. "heaven eternal man"). A. Waley speculates that this epithet 
Mongols do in fact emphasize eternity over the everlasting by observing the deference they show divination as a heavenly medium. In scapulimancy, for instance, a particular fate mandated by heaven is made manifest in the sudden cracking of a sheep bone subjected to intense heat. With the momentary cracking of the bone the heavenly mandate is clearly eternal, not everlasting. ${ }^{48}$

The legitimacy of the institution of the khan comes from heaven. Heaven's favor belongs to the khan. Heaven ordains the khan to rule. This is his destiny. ${ }^{49}$ The khan traces his origin from a heavenly genealogy. ${ }^{50} \mathrm{He}$ is the Son of Heaven. ${ }^{51}$ Heaven affords the khan protection (ibegel) and charisma (sülde). ${ }^{52}$ His followers elevate him to the khanship. They raise him up on a felt carpet. The earthly carpet on which he sits symbolizes the heavenly firmament. Thus his investiture marks the union of heaven and earth under one government. ${ }^{53}$ To the khan the reins of the heavenly chariot are loosed. The way of rule is opened for him. He rules the lives of common people as heaven does. His rule is consubstantial with heaven itself. He possesses the power to bind. That is, he determines fates of others, and he and his descendants will continue to do so as long as they continue to succeed. His rule is affirmed by heavenly signs. Reliance on heavenly signs in government implies that the khan has the power to know and to predict celestial phenomena. ${ }^{54}$

likely translates Chinese shenxianren神仙人 “divine immortal.” Given this reputation, Chinggis Khan asks Changchun of his medicine to which Changchun replies, "I have means of protecting life, but no elixir that will prolong it." Chinggis Khan is said to have been pleased with his candor (Waley 1979: 101). The Mongol khans regularly asked the priests in their service to pray for their longevity, and they remembered their ancestors and fallen heroes after death. The extent to which Chinggis Khan was held to live and reign forever after death is an open question.

48. For the practice of scapulimancy in Mongolian tradition, see, for instance, Juvaini (1958: 137-138); Rockhill (1900: 187-88); and Olbricht and Pinks (1980: 77, 140);

49. See Secret History $\S 1, \S 21$ (de Rachwiltz 2006: 1, 4, 225). According to Beffa (1993: 218) there is no mention of predestination in relation to the ascension of Chinggis Khan in the Secret History. Becoming khan is strictly a human affair. This view misses the forest for the trees. The Secret History concerns the origin of Chinggis Khan. Every word of it leading up to the fact itself shows that he is predestined by heaven to rule. Beffa is correct in the sense that his right to rule depends on right action, action legitimized by heavenly charge.

50. de Rachewiltz (2006: 1, 221-226).

51. See Secret History $\S 21$ (de Rachwiltz 2006: 4, 225). The epithet "Son of Heaven" (Ch. tianzi $i$ 子) is given to the emperor in Chinese dynastic tradition. The epithet is also known in the West. See DDD (s.v. "Son of God"; "Sons of (the) God(s)").

52. de Rachewiltz 2006: 229.

53. Olschki (1949: 30-34); Sela (2003).

54. See references to "heaven" in de Rachewiltz (2006: passim, 1275). 
Heaven gives authority not only to the khan over all other people but to the

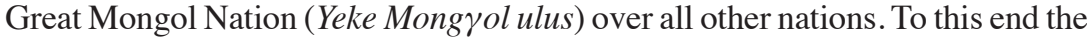
khan and those in his immediate family purposely intermarry with those in his retinue and with his allies. Together united by the ethnonym, "Mongol," they and their families comprise the ruling elite. The Mongols'practice of intermarriage shows deference to the power of heaven in that the act of intermarriage brings people of alien origins into the fold of the heavenly-originated genealogy. Known as the Golden Clan (altan uru $\gamma$ ), it is the substance of gold that sets them apart from all other nations as being heavenly originated, for gold was a widely recognized figure for heaven. ${ }^{55}$

Such a travesty has been made of the Mongols in scholarship it bears mentioning that the pre-Buddhist Mongols were neither merely a tribal people; nor were they merely nomadic-pastoralists and hunter-gatherers. In their heavenly origin the Mongols were, first and foremost, aristocrats. Their government was designed to rule not only themselves but others as well. Moreover, the Mongols'government was a martial government. The pre-Buddhist Mongols were, from birth to death, nomadic steppe warriors. Like the Scythians of yore, their first order of business was military. They were a permanent threat and source of constant fear to neighboring settled peoples. Animal husbandry provided the Mongols their sustenance. This was not, however, their calling. They lived and died to be heroes (ba'atur), not herders.

In The Headless State D. Sneath does much to mitigate misconceptions of the Mongols fostered by what he calls Anthropologists" "colonial-era notions of tribalism." ${ }^{56}$ Yet, his provocative study of Inner Asian aristocracy, kinship, and nomadism continues on in the Anthropological tradition of putting theory ahead of fact. ${ }^{57}$ Sneath's notion that the state in Inner Asia was a "headless" configuration formed by horizontal relations between power holders is contravened by the wisdom of Chinggis Khan as told in Juvaini's History of the World Conqueror. ${ }^{58}$ Here Chinggis Khan warns his sons that after his death they must work together so that, as a frail arrow when bundled with others becomes unbreakable, they can resist their enemies. But at the same time, he tells them, they must look to one as the leader of the rest. For a state without a leader, he tells them, is like a snake with many heads. When winter comes it knows not which hole to enter

55. If people drive a common wagon, the heavenly Wagon (Boötes) is a Golden Wain. If people eat ordinary apples, the apples of heaven are golden apples. The heavenly dome of the firmament was said to be made of gold. Such examples are endless. See Allen (1963: passim).

56. Sneath 2007: 1 .

57. See also Golden (2009); Sneath (2010); and Golden (2010).

58. Sneath 2007: 1 . 
and perishes in the cold. Thus it is decided among them that authority over the empire as a whole would be invested in one man, the khan of khans or qa'an. ${ }^{59}$ In the Mongol Empire "a headless state" would describe a condition of discord between opposing factions. Such was often the case in fact, but it was not the ideal. Michal Biran rightly describes the Mongolian model for state formation as primus inter pares. ${ }^{60}$

Deference to the primacy of place characterized Mongolian society to such an extent that foreigners were astonished by it. In visiting the ordu of Batu Khan (d. 1255), William of Rubruck found it remarkable that every Mongol knows his place. This knowledge extends to the site where each pitches his tent as they move from camp to camp. It reminds him of how the people of Israel all know their place in the tabernacle. ${ }^{61}$ To this day, when one enters a Mongolian ger his place awaits him.

The Mongols power over their subject peoples was deferred in rhetoric to the power of heaven. In conceiving of heaven in symmetry as the source of knowledge for governing the earth, we realize that this prescription is tantamount to saying that they ruled others by the power of superior knowledge. In their correspondences with foreigners they make this similitude overt when they write, should you not submit to us, heaven knows what will happen to you. ${ }^{62}$ The superiority of their knowledge was tangible. They were the masters of every situation. Not only did they vanquish their foes in battle - often when greatly outnumbered, they outstripped all others when it came to logistical knowledge, knowledge of geography and how to use the land to their advantage. They possessed superior technologies and gave much attention to research and development. They thrived economically. Their material prosperity entailed knowledge of commodities, goods and services, markets, and efficient transportation across vast expanses of land and sea. And they succeeded in their propaganda, which required knowledge of the humanities, literature and history.

59. Juvaini 1958: 41-42.

60. Biran 1997: 7ff.

61. Rockhill 1900: 122.

62. We find this rhetoric, for instance, in the famous 1246 letter of Güyük Khan (r. 12461248 ) to Pope Innocent IV (r. 1243-1254) in Dawson (1955: 85-86). Juvaini (1958: 25-26) tells us that rather than threatening others with the size of his territory or the power of his army, he says merely, "If ye submit not, nor surrender, what know we thereof? The Ancient God, He knoweth." See also the enigmatic speech of Bodonchar in the Secret History of the Mongols (de Rachewiltz 2006: 7). 


\section{Priests}

Serving the Mongol khans as keepers and purveyors of knowledge were various traditions of priests. The central function of these priests was to deal in the ways of heaven. In the early years of the empire, priestly tradition was hereditary with the most prominent priests coming from the Qongqotan clan. ${ }^{63}$ Sometime after 1206 the power and influence of the priests of the Qongqotan clan was greatly diminished. By this time their role as keepers and purveyors of knowledge was already being appropriated by foreigners. Along with various pathic arts and forms of divination, the Mongols'priests studied the heavens. ${ }^{64}$ William of Rubruck notes carefully that some of their priests, especially those chief among them, were skilled in astronomy and foretold eclipses ${ }^{65}$ Precisely what is meant by "astronomy," however, is again an open question. Did their skill embrace mathematical astronomy (in Neugebauer's sense of the term) or did they merely observe heaven with the aid of a gnomon? That they were able to predict eclipses does not necessarily indicate the use of mathematical astronomy. ${ }^{66}$ Either way, by all accounts their knowledge of astral science was rudimentary in comparison with that of their more civilized neighbors. ${ }^{67}$

Through the influence of the renowned anthropologist, M. Eliade, we know the Mongols'priests by the term "shaman." ${ }^{8} \mathrm{~A}$ word of Tungusic origin, we associate it loosely with that which is indigenous to Siberia and utterly primitive.$^{69}$ In addition to the Mongols's priests, the term "shaman" has been used to designate priests of numerous peoples throughout the world. The general

63. De Rachewiltz 2006: 878, 887-888.

64. Juvaini 1958: 59.

65. Dawson 1955: 197.

66. For the predicting of eclipses in antiquity, see Needham (1959: 420-421); and Baumann (2008: 140).

67. Su Tianjue's biography of Yelü Chucai in the Yuan chao ming chen shi lue (5) says that at the beginning of the empire the Mongols lacked astronomical knowledge altogether. This should be taken with a grain of salt. From Tianjue's account we infer that it is not that they did not pursue astral science, but, rather, that their knowledge was poor. As Tianjue notes, they predicted eclipses - but not accurately. See also Juvaini's statement that the Mongols once upon a time had no science or knowledge (1958: 59). Even so, he mentions that they used astrology to settle upon an auspicious moment for the inaugurations of Ögedei in 1229 and Güyük in 1246 (Juvaini 1958: 187, 258).

68. Eliade 1964.

69. Facile associations of "shamanism" with techniques of ecstacy and that which is primitive and indigenous to Siberia have developed from Eliade's influential work. However, Eliade's Shamanism itself is thorough and nuanced. Though the discussion of Eliade's contribution is beyond the scope of this essay, we do not want our comments concerning general perceptions to be taken as a judgment on his work. 
study of these priests has spawned a whole subsect of Anthropology known as "Shamanism." Under this discipline Mongolian tradition is frequently compared with the practices of peoples, whose common heritage with the Mongols, if it exists at all, has been broken by an indeterminate period of several millennia. By the same token the discipline tends to downplay apparent connections to the various priestly traditions of the nations of Eurasia. ${ }^{70}$

Though the study of "Shamanism" is not without its merits, this view of the Mongols'priestly tradition is misleading. The pre-Buddhist Mongols did not know their priests as "shamans." Nor did they associate their priests'knowledge with that which is primitive and indigenous to Siberia. The Mongols'priests were known by terms such as qam and böge. As Turkish was something of a lingua franca across the empire, qam, a Turkish word for "priest," tended to be used by foreigners. The latter term tended to be used by the Mongols themselves. Mongolian böge too shows Turkish influence on Mongolian culture. Deriving from Old Turkish bögü, it means "sorcerer, wizard, soothsayer, or magician."71 These terms conjure dramatically different connotations than does "shaman." When we think of magicians, we think of the sophisticated priests of the ancient Near East (which to the Mongols was the West) who used their knowledge of heaven and its rhetoric to oversee the governance of large empires. Particularly, we think of the Magi proper, the priestly clan who figured so prominently in the establishment of the Achaemenid Empire (550-330 BC), which extended from the Mediterranean Sea deep into Central Asia. ${ }^{72}$

\section{Ecumenism}

Given the scope of this essay, to duly span the chasm separating these opposing views of the Mongols'priestly tradition proves a bridge too far. Rather,

70. Though we look critically on the conceptual underpinnings of the discipline, we do not question its value. Priestly traditions did and do exist. Individual studies on "Shamanism" have their own merits. We believe that grounding in the first principles of science and a working knowledge of the ways of heaven would benefit the discipline immensely. Again, we do not want our comments to be taken as a judgment on individual works.

71. Clauson (1972: 324); Doerfer (1965: 233-234); and Boyle (1977: XXII, 178).

72. For the magi, see Boyce (1982: passim). Note, for instance, their hereditary standing $(9,19-20,85-87)$; their respect for the color white $(21,107,147)$; their function as propagandists for the emperor $(43,46-48,154-155)$; their traditions of interpreting dreams $(67,165)$ and taking omens $(167-168,180,183,215)$; how they would accompany the armies (165ff.); and how they held their own army (288); their practice of the rite of exposure to the elements (182); their responsibilities for cosmogony and cosmology; and their work in the fields of astral science $(33,234-235,241,260)$. 
we would like to fit the subject within the greater question of the degree to which Mongolian practices derive from the observable heavens and conform to the traditions of other peoples. Here we want to be clear. In pursing the question of cross-cultural affinities we by no means deny the existence of a unique TurkoMongolian tradition with Inner Asian roots tracing back to the Han dynasty-era empires of the Xiongnu. Nor do we discount the profound influence of Chinese culture on the Mongols'practices concerning heaven. Indeed we feel Chinese influence to be often underestimated. Neither do we deny the possibility that some semblance of continuity between the Mongols'traditions and those of Native Americans, Pacific Islanders, and such peoples with whom their practices are frequently compared might possibly exist. ${ }^{73}$ Rather, we want to say, first, that there is no greater affinity between the Mongols'traditions and those of Native American, Pacific Islanders and so on than there is between the traditions of these peoples and those of the peoples of Eurasia in general. More importantly, we want to stress that in the time of the Mongols, and, indeed, long before, an ecumene existed spanning the full sweep of Eurasia. The Mongols irrefutably belonged to it. The ecumene came with a depth of history. To this history belonged not only the ways and deeds of Turks and Chinese but those of the peoples of Western Asia as well. Long before the rise of the Xiongnu confederacy and the Han dynasty in China, the civilizations of Western Asia had established the prototypes of empire, how to govern multifarious peoples and vast tracts of earth by means of the natural symmetry with heaven. One would expect that the Mongols'tradition derives in some way from those that came before. After all, they build an imperial government, and they use the rhetoric of heaven to do so. Yet when we view the Mongols'tenggeri as ultimately "religious," imaginary and unempirical, our tendency is to look at various aspects of their culture individually and take them at face value. From this point of view it does appear as if their culture is like no other and exceedingly primitive. However, when we view Mongolian practices as expressions of government in the context of symmetry with a scientific, empirical heaven, a very different view emerges. ${ }^{74}$

It bears remembering that pre-Buddhist Mongolian culture shares much in common with that of the Turks. Turkish culture in turn is broadly influenced by Sogdians and the Persian world. In the comparative lexicon Dīwānü Lugiāt it-Türk (c. 1007) of Mạ̣mūd al-Kāshgharī the close cultural affinity between the Turks and the traditions of the ancient Near East is clear in terms of language and intellectual and material culture. Specifically in terms of heaven, G. Clauson notes that we have no history of a time when the astral traditions of the Turks

73. See, for instance, Pedersen (2001: 411-427).

74. For an antithetical approach, see Beffa (1993). 
were not influenced by the traditions of their neighbors. ${ }^{75}$ The Turks'close affinity with Near Eastern traditions is evident in al-Biruni's Chronology of Ancient Nations (A.D. 1000). ${ }^{76}$

As far as the Mongols'pre-Buddhist culture is concerned, though our knowledge of their astral systems is a separate, more complicated issue, a vast preponderance of rituals and themes in their tradition have antecedents in the greater ecumene. To thoroughly prove this point is beyond the scope of this essay. However, a brief list of examples might suffice to demonstrate it.

It is well known that the Mongols had a fire cult whereby all who came into the presence of the khan had to purify themselves by passing between two fires. So too in ancient Iranian tradition the innocent person underwent a trial by fire in which he passed successfully through two roaring fires. ${ }^{77}$

In the Secret History of the Mongols we have a number of examples of widely known divination techniques, which, though not unheard of in Chinese tradition, in their specific motifs are reminiscent of Near Eastern types. For instance, we have an example of dream divination or oneiromancy in Dei Sechen's dream of a white gyrfalcon holding both sun and moon. ${ }^{78}$ Following the desecration of the severed head of the Kereyit leader, Ong Khan, at the hands of Dayang Khan and his Queen Gürbesü, the sound of barking dogs makes for a common omen protasis. ${ }^{79}$ And prophecy is the method used in Qorchi's proclamation that "Together Heaven and Earth have agreed: Temüjin [Chinggis Khan] shall be lord of the people"! ${ }^{80}$

Mongolian people, especially soldiers, are known to have kept a number of traditions related to weather and the natural environment. For instance, they refrained from bathing in streams; recoiled in fear and covered their ears at the peal of thunder; and practiced weather magic by means of a certain stone called jada (Tu. yada) ${ }^{81}$ For these traditions one might assume the Mongols to have

75. Clauson 1964: 351.

76. See also Ginzel (1906: passim); SETF II 290-411; and Bazin (1991).

77. For the Mongols'fire cult, see Poppe (1925); Mostaert (1962); Heissig (1980: 69-76); Ratchnevsky (1970: 417-443); Rockhill (1900: XXX-XXXII, 34-36); Boyle (1977: XIII, 560); Amitai-Preiss (1991: 355 ff.); and Titzherbert (2006: 399). For the Iranian fire cult, see Boyce (1989: 35; 1982: 222-223).

78. de Rachewiltz (2006: 14). Compare this falcon to the sun and moon bearing, good fortune bringing, khvarenah of the Iranians (Boyce 1982: passim).

79. de Rachewiltz (2006: 110-111). For omina in general and the dog's call as an omen protasis in particular, see Baumann (2008: 184-190).

80. de Rachewiltz (2006: 28).

81. Concerning the summertime prohibition on bathing and its tie to their rituals of thunder, see Juvaini (1958: 205-206); for their rituals of thunder and lightning see the accounts of the Song envoys Zhao Gong and Peng Daya and Su Ting (Olbricht and Pinks 1980: 
been fearful of nature and superstitious. Yet these traditions are just as well found in the Near East where the midsummer heliacal setting of Regulus, the star of the emperor, was accompanied by various signs. People were prohibited from bathing. Thunder foretold sedition and the deaths of great men. ${ }^{82}$ In this context to avoid bathing in a stream or to cover one's ears at the sound of thunder shows loyalty to the emperor. We do not know what, if any, stars mattered to the Mongolian traditions, but we might assume that their traditions too were done out of loyalty to the khan and in symmetry with the ways of heaven. After all, as noted by Peng Daya and Su Ting, all Mongols'remember daily in all of their affairs the power of heaven and the protection of the khan. ${ }^{83}$ If so, in this context of symbolic, ritual symmetry between heaven and earth, as bathing and thunder mean something more than their literal denotation, there is no reason whatsoever to assume the Mongols were any more afraid of these things than were their Near Eastern predecessors or anyone else for that matter.

Likewise weather magic by means of the bezoar stone was just as well known in the Near East as it was in Inner Asia. ${ }^{84}$

Consider the following: With Chinggis Khan's Western Campaign (12191224) bogged down in and around India, the sighting of a supernatural animal with a deer's body, horse's tail, green, and with a single horn becomes a sign for the Mongols to return home. The meaning of the sign is interpreted by Yelü Chucai, the famed astronomer. Knowing both that Chucai was an astronomer and that such creatures are commonplace in the makeup of heaven (where they are by no means imaginary), it behooves us to seek a figurative solution, a common astral trope, in answer to the question of what was this creature. When we do, we find a figure, in Chinese a qilin 麒麟 that suits the description perfectly. ${ }^{85}$ Yet, against this very natural, allegorical explanation, scholars force a contrived, literal explanation of the creature when they propose that the beast may have been a rhinoceros. In taking what is in all likelihood an allegorical

passim). Note in Waley (1979: 115) how the Daoist priest emphasizes ethical devotion to one's parents over rites concerning thunder, bathing in rivers, and so on. This protestation belongs to a greater trend emphasizing morality over amoral ritual. For the tradition of "thunderstorm stars" in Arab tradition, see "Zur Tradition der "Unwetterssterne"” in Kunitzsch (1989: XVI).

82. Allen 1963: 252-253. Vahman 1986: 209. See also the legend in the Bhägavata-purāna (5.8) of Bharata being reborn as a deer (BhP 669ff.). See also Keith (1981: 452); and Jones 1949: 5.

83. Olbricht and Pinks 1980: 141.

84. For weather magic, see de Gubernatis (1978: 421-23); Utz (1998); de Rachewiltz (2006: 525); and Molnár (1994).

85. For the lin in Chinese traditions, see, for instance, Shijing (1.11) in Legge (1985: 19). 
allusion for a literal creature our perception of the Mongols changes dramatically. As people who couch their decisions in complex, esoteric, astral allegory, the Mongols appear to us as erudite and worldly. As people who base major decisions involving hundreds of thousands of people on the random sighting of an exotic animal, they appear to us as superstitious and naïve. ${ }^{86}$

As another example, scholars often speculate on the reason the Mongols never returned to Europe after suddenly foregoing their successful campaign under Batu in 1241. Scholars present various arguments. Some argue that their enemy was too fierce; others argue the pastures had not enough green. In arguing against these rational, plausible explanations, scholars occasionally turn to passages in William of Rubruck and Juvaini stating that the Mongols would have returned to Europe if their diviners had allowed it. ${ }^{87}$ In these rebuttals we are allowed to assume that there may well have been no rational explanation for the Mongols'decision whatsoever; this, because their sorcerers were given to irrational, ecstatic, and random methods. The argument seems lock-tight except when we remember that the same sources also tell us that the Mongols used some form of divination before finalizing every single decision that they made.$^{88}$ Are we to assume then that they conquered the world by random chance and dumb luck?

Forgotten in this line of thinking is the fact that Mongolian divination methods were carried out within a context of symmetry between heaven and earth. Take the practice of scapulimancy as an example. Zhao Gong, the Chinese envoy to Chinggis Khan's camp in 1221, tells us that they make decisions by striking sheep scapulae with a red-hot implement and then reading the omens in the way the bone cracks. (Here we should point out that the Mongolian tradition reminds Zhao Gong of ancient Chinese divination technique) ${ }^{89}$ Zhao also tells us that they do so in the context of asking heavenly favor for their course of action. In other words, they make a plan of action and then offer that plan up to heaven. ${ }^{90}$ In this, heaven, not the shoulder bone, sanctions the action. The scapula is merely the medium of divination. Thus, paradoxically, in context of symmetry between heaven and earth, it is the randomness of the divination

86. There is nothing wrong in speculating on an historical antecedent to a heavenly sign. The question is one of emphasis. Do we emphasize the literal account or the astral allegory? To insist upon the literal account to the exclusion of astral allegory shows a fundamental problem. See de Rachewiltz (1993: 141-142); and Baumann (2008: 292).

87. Dawson (1955: 197); Boyle (1977: I, 15; V, 340); and Halperin (2000: 230).

88. Dawson (1955: 197); Juvaini (1958: 59); Boyle (1977: XIX, 208).

89. Eno (1996: 41-42). See also the views of later Song envoys, Peng Daya and Su Ting (Olbricht and Pinks 1980: 140).

90. Olbricht and Pinks (1980: 77). 
method that proves the deterministic fatalism of heaven and so signifies that the final decision is perfectly well-ordered and reasonable.

\section{Zoomorphism}

Because of their prominence, special attention needs be paid the animals of the Mongols'pre-Buddhist tradition. The Mongol khans are often seen handling white gyrfalcons. They hunt with eagles, big cats, and mastiff dogs. They decorate their belongings with images of dragons and phoenixes. Their ethnogenetic myth begins with the union of a blue-grey wolf and a fallow doe. Together this ritual use of animals is taken by scholars to constitute a cult unto itself, a cult referred to as "animism." This "animism" is held to originate in the Mongols'ancient, primitive shamanic heritage. ${ }^{91}$ Although those who hold this view do not necessarily share the implication, this view of the Mongols'ritual use of animals ties into a greater narrative of human evolution and the supremacy of Western Civilization and Modern Science. Thomas Kuhn (1957: 95), discussing the Aristotelian worldview in The Copernican Revolution: Planetary Astronomy in the Development of Western Thought notes that although today the educated and adult view of nature shows few important parallels to Aristotle's, the opinions of children, members of primitive tribes, and of mentally regressive patients do parallel his with surprising frequency. These views, he says, tend to be animistic. They do not draw hard distinctions between organic and inorganic nature. Under this evolutionary rubric, discussing the Mongols'ritual use of animals from the point of view of primitiveness and shamanism makes us believe not only that the Turko-Mongolian animism is indigenous and uninfluenced by its neighbors but also that it is mutually exclusive of their cult of heaven.

Contrary to this view we note that many of the animals found in the Mongolian tradition are in some way foreign. Often, as in the case of lions and peacocks, the animals themselves are not indigenous to the Mongolian native lands. Sometimes, as in the case of dragons and phoenixes, the animals are not even incarnate. Frequently their names are loan words. And many of these names originate to the Mongols'West among Iranians and other peoples. For example, we have Mongolian to $\gamma u s$ "peacock" from Persian tāus; Mongolian singqor from Persian sungqur "falcon." Mongolian bars from Persian pars. Usually translated "tiger," the term principally refers to a "panther" and then to any number of big cats including "tiger, lion, leopard, and cheetah."

91. See, for instance, Pedersen (2001), who broadly surveys the notion of "animism" in differentiating it from "totemism." 
In addition to the very foreign makeup of the Mongols'cult of animals, the animals themselves transcend their own individual species. That is, their representations are not literal but figurative. They belong with, and represent aspects of, heaven. To make an easy example, the term bars "tiger" occurs twice in the Secret History, but it does not refer to an actual tiger in either case. In both instances it refers to a figurative tiger, a constellation in the Chinese zodiac used to mark chronology. ${ }^{92}$

In antiquity the Egyptians were famous for elevating their cults of animals to the sky. In doing so they did not abandon their animism. ${ }^{93}$ We find the same trend across the known world. Though everything under the sun was posited to it, the sky became principally known through animals. The Western and Chinese zodiacs are but modest examples of this trend. When one studies the star lore of various traditions, Egyptian, Mesopotamian, Indian, Iranian, Greek, Hebrew, Chinese, or what have you, one finds that peoples had multiple star systems and that their signs were signified by a great plurality of animals. Hebrew prophetic literature appears to be animistic in its references to owls, ostriches, jackals, and kites haunting the deserts of forsaken peoples. However study of Mesopotamian astral science makes it clear that these animals have their place in the sky, as well. ${ }^{94}$ The peacock designated various stars, including stars of Aquarius and Gemini. It symbolized various deities, including Hera and Indra. Its blue color and the array of "eyes" covering its outspread tail-feathers were a symbol of heaven itself. ${ }^{95}$ The falcon for the Egyptians represented numerous manifestations of the god Horus as various celestial bodies, the sun, Jupiter, Saturn, and Mars. ${ }^{96}$ The Iranian's symbol of the sun as a falcon is held to be influenced by Egyptian tradition, which was widely disseminated throughout the Near East during the second millennium BC. ${ }^{97}$ As a potent symbol of the power of heaven, heavy trade in Saker falcons, known for their white color, originated in the Iranian homeland in the Badakhshan Mountains. ${ }^{98}$

A characteristic of the Mongols'animism is a preference for white or albino animals. Yet, the same preference is found across Eurasia where animals of a white color were prized as the purest forms of the astral antecedents they

92. De Rachewiltz (2006: passim).

93. See Plutarch's Isis and Osiris.

94. Study the pre-Ptolemaic Arab tradition, best discussed by P. Kunitzsch (1961). For the more ancient Mesopotamian tradition, see Hunger and Pingree (1999).

95. Allen (1963: 46, 225, 320-321); de Gubernatis (1978: 126, 251).

96. Pritchard (1954: 189; 1969: 367-368); Clagett (1989, v.1: 281-282; v.2: 245-246); Neugebauer and Parker (1960: 44-45)

97. Boyce (1982: 37-38, 104, 287-288; 1989: 88-89, 10).

98. Yule (1929: v.1, 158). 
represented. The Egyptians designated their zodiac through metonymy as the sacred White Ibis. ${ }^{99}$ For the Greeks, snowy white in color are Pegasus the Horse and Taurus the Bull. ${ }^{100}$ In China the stars of Aries, Taurus, and Gemini, which in that tradition comprise heaven's western sphere, were known as the White Tiger. ${ }^{101}$ In India the Four Heavenly Kings or Mahārājas ride white elephants. ${ }^{102}$ In the Book of Enoch stars led by a white bull, symbol of Adam, descend from heaven to mate with snow-white cows. ${ }^{103}$ For Iranians heaven is personified as having a white body. ${ }^{104}$ The chariot of Jupiter is drawn by white horses. ${ }^{105}$ The sign of Tistrya, the star Sirius, is a beautiful white horse with golden ears and a golden caparison. ${ }^{106}$ White stallions are yoked to Mithra's heavenly chariot drawing it on a golden wheel with a full shining axle. ${ }^{107}$

In this way, across Eurasia animals types were used in government as zoomorphic representations of heaven. There can be no mistaking this. The Near Eastern tradition, which coalesced during Achaemenid and Hellenistic times but embraces a wealth of types that are very diverse of origin and very old, set a precedent for imperial government. It clearly influenced the Turks. How can it not have influenced the Mongols as well? The star Regulus (alpha Leonis) embodied a symbiosis between the emperor and the lion, the king of beasts. Could one who bore the familiar Turko-Mongolian title Arslan Khan 'Lion King'have been ignorant of this?

The symbiosis between heaven, animals, and earthly rule is made manifest through the tradition of a ritual hunt carried out by the nobility of different nations across Eurasia. The phenomenon is discussed in Thomas Allsen's The Royal Hunt in Eurasian History. Allsen's book dispels the notion that hunting needs always be merely hunting. The royal hunt across Eurasia, he carefully shows, served as a means of sovereign legitimation. As such, its practice was imbued with cosmological motifs the authority and provenance to which was recognized internationally as a tradition of the great governments of the ancient Near East. Even though one might associate the Mongols'hunting practices with a timeless indigenous culture, Allsen demonstrates that the Mongols'royal-hunt clearly belongs to this ancient Near Eastern tradition.

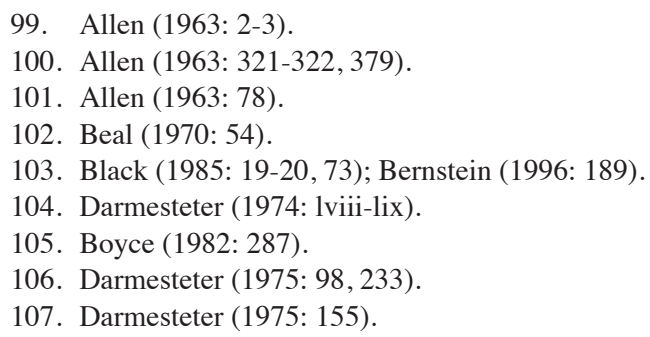


Unfortunately, however, the long-held view of the Mongols'culture as primitive and isolated does not fall by the wayside so easily. In a review of Allsen's book in Mongolia Studies, Paul Buell, after praising Allsen's thoroughness, discounts the book's reason for being as follows:

The biggest problem that the undersigned had with the book is that it views Eurasian royal hunts too much through Iranian-colored glasses and ignores the substantial differences that existed from culture to culture. The Mongols, for example, did not view the natural world in the same terms as the Iranians or others from the Middle East and their royal hunts took place often on an entirely different basis than did Iranian per se. For example, contrary to what Allsen seems to suggest, the Mongol court in China did not go hunting for the sake of staging a royal hunt, although the result might have been the same, but went on the trek as Mongols had always done.... In this connection, there is a significant difference between a sedentary court going out in the field for fun and to prove manhood and Mongols doing what Mongols had done since time immemorial. And if Mongol treks seem to have more characteristics of an Iranian royal hunt tha[n] [sic] they should have, we should remember that we see Mongols on the trek usually through the eyes of others, not their own, and this includes Iranian eyes. (84)

To say nothing of Buell's rather ludicrous demand that a comparative study treat individual cultures individually, note how Buell resorts to the Latin qualifier "per se" to make an absolute distinction between the Mongols and all others. To this we should add that Buell's assertion that nomads hold some special affinity for hunting that sedentary peoples lack is baseless. Sedentary peoples have been hunting "since time immemorial" too. As for by whose eyes we understand Mongolian hunting, although the question of method is one thing (and Allsen's is most sound), the effect of insisting that a Mongolist such as Allsen sees the Mongols'hunt through Iranian eyes but simply cannot see it through the Mongols'eyes implies that the Mongols'view of the natural world must be uniquely Mongolian. As such, the Mongols'tradition of hunting must be fundamentally different from the tradition of the royal hunt known to all other sovereign peoples across Eurasia. In insisting that the Mongols'view of hunting must be uniquely Mongolian, Buell's rhetoric again raises the specter of race. The Mongols'ignorance of the Eurasian royal hunt, Buell would have us believe, is due to the Mongols'predisposition for understanding nature in a way that is beyond the memory of time. Allsen's book does not concern race. It concerns history, the history of government, culture, language, and so on. Yet, sadly, note how viewing the Mongols'culture in racial terms as unique unto itself precludes the Mongols from these discussions. It is as if they are not of this world.

Left out of Buell's discussion altogether is the distinction between hunting for food and hunting as a means of political legitimation. Because hunting is 
especially vital to Mongolian culture does this mean that they must be ignorant of its use for political legitimation? To suggest that the type of hunting Allsen describes, whereby an overweight and gout-ridden Qubilai Khan rides out on an elephant-born palanquin leading myriads of people and unleashing a panoply of exotic predators imported from parts West to hunt prey confined within artificially constructed game preserves, constitutes an example of the way in which the Mongols have traditionally hunted for food is absurd. As it was, the Mongols expressly forbade others to hunt. They did so not because of scarcity of game but because it posed a threat to their legitimacy. (They had to rescind the law when people began to go hungry). ${ }^{108}$ Thus we have two aspects to hunting, one of heaven, the other of earth. The two may well dovetail into one and the same thing, but the hunting that we read about in our sources expresses yet another manifestation of the power of heaven.

\section{Continuity and Change}

Against the notion of the Mongols'culture as primitive and impervious to time is the fact that our sources show it to be changing very rapidly. The Mongolian plateau of Chinggis Khan's time was a very worldly place. Some fifty nations of Turkish and Mongolian ancestry dwelt there. These nations were interconnected with Chinese and western peoples through trade, that is, through tributary relations, and through religion. In addition to the nameless priestly tradition (which we wrongly dub "Shamanism"), Syriac-rite Christianity (or Nestorianism), Zoroastrianism, Manichaeism, Islam, the Brahman tradition, various Buddhist Orders, and the Chinese Three Teachings, Confucianism, Buddhism, and Daoism were all known to them. ${ }^{109}$ When Temüjin was elevated to the title Chinggis Khan in 1206, his fold of Mongols comprised a nation of nations. By this time they had adopted the Uygur writing system. This Aramaicbased system came to them not merely as a utilitarian means to an end but as a part of a longstanding tradition of learning with origins going back to the Achaemenids. It was yet another expression of the power of heaven. ${ }^{110}$

Within his lifetime Chinggis Khan would come to be served by priests of every fold within the purview of his realm. Especially important were Uygur scribes who from their native land at the nexus of the Silk Road kept multiple traditions as their own. Over time the prominence of foreign sages would

108. See the discussion of hunting in Yule (1929: v. 1, 396-410).

109. For an overview of Inner Asian life and culture at the time of Chinggis Khan, see Di Cosmo et al. (2009: 9 ff.).

110. Boyce 1982: 179, 279; Boyce and Grenet 1991: 57-58; Baumann 2008: 276. 
increase. After the conquest of the Jurchen Jin dynasty in 1215, Chinggis Khan enrolled the Khitan polymath, Yelü Chucai (1190-1244). Master of the Three Teachings, Yelü Chucai possessed a wealth of Chinese and Inner Asian learning. Through his participation in Chinggis Khan's campaign in the West beginning in 1219 Chucai learned the Western tradition as well from his station in Samarkand, then an important intellectual center. Two generations later the Mongols gained another renowned polymath when Chinggis Khan's grandson, Hülegü (r. 12561265), took from among the Ismā ‘īlīs Nașīr al-Dīn Ṭūṣī (1201-1274).

We mention these two well-known personages to raise the issue of -what to the Mongols was- Western influence on their culture. As Chinggis Khan moves west, we see him using correctly, and to his desired end, tropes familiar to, and originating in, the West. The question we ask is to what extent were the Mongols utilizing tropes from within a common heritage versus the extent to which they were simply assimilating new rhetoric? Islamic sources such as Juvaini's History of the World Conqueror show Chinggis Khan referring to himself as the "Scourge of God." In 1220 he tells the people of Bukhara that they have committed great sins. The proof of that sin is his very existence, for if they had not committed great sins, God would never have sent a punishment such as him upon them. ${ }^{111}$ The words seem contrived and anachronistic in Chinggis Khan's speech, but can we be certain the concept was unfamiliar to him? The "Scourge of God" trope, after all, a commonplace in the Near East from at least as early as Isaiah (10.119), was applied again and again to marauding steppe warriors from Chinggis khan's precursor, Attila the Hun, to Chinggis'successor, Timür (1336-1405). ${ }^{12}$

In another example, at the time of Chinggis Khan's death, his empire was divided up among four children of his principle wife, Börte. It just so happens that this act suits perfectly a common trope whereby the four directions are said to be guarded by four warrior kings and/or princes. The four directions, we remember, are consubstantial with the solstices and equinoxes, the colures; they function as foundational points to the heavenly order and world governments; and so are oft likened to pillars; they divide the world into four spheres; and so are oft likened to continents. ${ }^{113}$ Did Chinggis Khan know the trope, and did its majesty influence his decision to so divide his empire? Certainly Juvaini

111. Juvaini (1958: 105).

112. Battenhouse 1941.

113. The trope of the Four Warrior Kings who have conquered the Four Directions is attributed to the Magi priests who served the Persian kings. In the astronomical chapter of the Sassanid era Bundahishn, Ahuramazda appoints four stars or asterism as Generals to conquer the Four Directions and makes the Pole-star General of Generals over them (Henning 1942: 231-232). In Indian tradition these four warrior kings are well-known as the Mahārāja. 
understood the connection for he writes that Chinggis Khan had four sons who were "to the throne as its four pedestals and to the palace as its four pillars." 114 In Old Turkic we find a number of examples of the trope. In the Küli Chor Inscription (KC E12) located in Mongolia's Central Province (Töv ayimagh) we find reference to tört tigin "four princes" in attendance at the hero's funeral. ${ }^{115}$ In the Manichaean text fragments found at Qocho and studied by A. A. v. Le Coq we find reference to the tört ilig tngri "four heavenly sovereigns." ${ }^{116}$ And in the Kül Tigin Inscription (KT N13) we find attested as a personal name the term Maqarač for the Indian Mahärāja, the famous warrior kings who guard the four directions. ${ }^{117}$ These evidences strongly suggest Chinggis Khan had propaganda foremost on his mind when he divided his empire.

Another commonly known western trope widely used by the Mongols is that of world dominion under one king. Scholars note that although tentative attestations of the trope are cited in the Secret History of the Mongols and Turkish sources, the trope is firmly attested in Mongolian sources only from the reign of Ögedei (r. 1229-1241) forward. Throughout Eurasia the trope takes numerous variations that would be lengthy and difficult to explain. We find it in Daniel (8.27). We know one variation on the theme in the figure of the Buddhist cakravartin. In Christian tradition (Matthew 4.1-11) the idea of one earthly king ruling all the nations of the world is repudiated as a fool's game. Given its Western heritage, Peter Jackson follows David Morgan in questioning whether or not the goal of world domination existed during Chinggis Khan's time. ${ }^{118}$

We do not intend to pursue the question here except to raise two points. First, given the lacuna, how we speculate is determined by our first principles. If we see the Mongols'culture as primitive and indigenous, this leads us to a negative conclusion. We might be tempted to assume otherwise, however, if we were to see their culture as sophisticated and integrated with other cultures of the known world. ${ }^{119}$ Second, although the notion of one world rule is as at least as old as the age of Herodotus, we tend to forget that the notion's realization in practice

114. Juvaini 1958: 40.

115. Tekin 1968: 258, 295. See also MNTSD (213).

116. SETF I 460.

117. Tekin 1968: 237, 272.

118. Jackson (2006: 3-22).

119. Simply to add to the discussion of the issue we note that in Su Tianjue's biography of Yelü Chucai, Chucai also makes the claim that Chinggis Khan desired to conquer the whole world. See his Yuan chao ming chen shi lue [Sketches of the Yuan dynasty's eminent ministers] (5). 


\section{Brian Baumann}

does not come until modern times. ${ }^{120}$ Whereas modern people think that to rule the world means to rule the entire extent of the spherical earth, to the medieval mind world rule was relative. To rule the world meant simply to hold a kingdom. We see this relativity to world rule, for instance, in the Kül Tigin Inscription where, when it comes to world-wide dominion, we read:

Eastwards to the sunrise, southwards to the midday, westwards as far as the sunset, and northwards to the midnight - all the peoples within these boundaries (are subject to me). ${ }^{121}$

And we read:

(All the peoples living in) the four quarters of the world were hostile (to [my ancestors]). Having marched with the armies, they conquered all the peoples in the four quarters of the world and subjugated them. ${ }^{122}$

Yet at the same time the Turkish realm is just as well defined according to earthly limits.

If the Turkish kagan rules from the Ötükän Mountains there will be no trouble in the realm. I went on campaigns eastwards up to the Shantung plain; I almost reached the ocean. I went on campaigns southwards up to Tokuz-Ärsin; I almost reached Tibet. Westwards I went on campaigns up to the Iron Gate beyond the Pearl River, and northwards I went on campaigns up to the soil of Yir Bayïrqu. A land better than the Ötükän Mountains does not exist! ${ }^{123}$

Thus the extent of any given government was couched in the rhetoric of world dominion. Certainly Ching gis Khan held this relative notion of world dominion. Otherwise he could never have held the reins of power. This notion existed long before Chinggis'time and does not suddenly crop up after his death. After all, the Mongols were from the outset a martial people ordained by heaven with a charge to rule the world. As to whether Chinggis Khan intended to extend his world dominion to include the Franks, Japanese, and other nations his descendants would eventually seek to pacify, this is purely speculation into the mind of a man. ${ }^{124}$

120. For the scientific underpinnings to the historical notion of "One World Rule," see Roller's (2009) study of Eratosthenes and Geus'(2011) review.

121. Tekin 1968: 261.

122. Tekin 1968: 263.

123. Tekin 1968: 261.

124. See also Turan (1955); Fletcher (1986: 31); and de Rachewiltz (2007: 127-130). 
These examples demonstrate that the Mongols'pre-Buddhist culture maintains more internal continuity and, yet, at the same time, shows closer affinity to West Asian traditions, than scholars tend to assume.

As a telling example of the pervasiveness of the rhetoric of heavenly allegory in Mongolia tradition, consider the very common term dalai, familiar to people the world over in the title Dalai Lama. Though defined as "ocean" or "sea," scholars note that in sources, especially pre-classical sources, the term usually refers to something more abstract, that which is "all-encompassing" or "worldwide" like unto the ocean. Thus on the seal of Güyük Khan's famous letter to Innocent IV in 1246 scholars do not translate the title dalay-in qan in a literal way as "Ruler of the Ocean" but in some manner of "Ruler of All."

To this we add that in celestial orientation the term "ocean," among its many meanings, refers to the horizon whereby stars rise and set. As the stars define any given realm, from the realm of one's own body to the realm of the spherical earth itself, supernaturally the "ocean," as a figure for the horizon that limits a given realm, expands and contracts depending on one's point of view. ${ }^{125}$ One might say that it expands from one's finger tips all the way to the celestial equator. This heavenly denotation is attested in Old Turkic in the terms taluy "ocean," tört taluy "four oceans" (in reference to the four quarters of the sky), and taluy ögüz "ocean stream." 126 The heavenly denotation is clearly attested in Mongolian as well in Sultan Öljeitü's 1305 letter to Philip the Fair of France. ${ }^{127}$ Knowing that the heavenly figure is attested in Turko-Mongolian letters, when we apply this definition to instances of the term in literature we find time and again that it brings clarity of meaning to what was once opaque.

For instance, in the Secret History of the Mongols the term dalai "ocean" occurs four times. In one of these $(\$ 253, \ln .10218)$, the term seems to refer to a literal body of water. ${ }^{128}$ In its three other occurrences, however, dalai seems to refer to a figure of celestial orientation. ${ }^{129}$ To take one example, in $\S 245$ (ln. 9806) we have an occasion for hyperbole when Mönglik, father of the deposed Teb Tenggeri, reminds Chinggis Khan of their long friendship. I have been your companion, he says:

125. Aratus 1997: 115; Burgess 1860: 390-391.

126. SETF I 355, ln. 1986; II 56-57, 68, 172; Clauson 1972: 502; Tekin 1968: 150; 1993: 8 n. 3; Sinor 1972: 117-118; Röhrborn 1971: 42, 45; Zieme 1996: 194, 200.

127. Mostaert and Cleaves 1962: 55 ff. Sinor 1972.

128. Here Chinggis Khan sends his younger brother, Qasar, on campaign along the Bohai seacoast (dalai gijin) with the left wing of the army (de Rachewiltz 2006: 181, 920-921).

129. § 199 (ln. 7409); § $245(\ln .9806)$; and § $280(\ln .11902)$. 
dayir etügen-i danglasun-u tedüi büküy-ece

dalai müren-i qoroqan-u tedüi büküy-ece

[Since the brown earth was no more than a clod of dirt

Since the ocean river was no more than a creek.]

Igor de Rachewiltz, who follows Antoine Mostaert in both his explication and translation of the passage, translates the phrase dalai müren (literally 'ocean river') as "sea and rivers," and he renders the line dalai müren-i qoroqan- $u$ tediii büküy-ece "Since the sea and rivers were only the size of a rivulet." 130 However, in taking the phrase dalai müren to refer to literal, disparate bodies of water, he overlooks the fact that dalai müren merely stands as the Mongolian version of Old Turkic taluy ögüz "Ocean River," a figure for the World Ocean or the horizon that limits a given realm.

How then do the two different readings of the phrase dalai müren affect the overall meaning of the passage? In its literal sense as "sea and rivers" (which is not a literal translation of the terms themselves) the phrase elicits an intellectual response. To think of a literal body or bodies of water makes the passage seem to concern an objective, remote reality; a reality of timeless antiquity; a reality detached from the interlocutors themselves; a fanciful reality, which can only be imagined. However, in its allegorical sense (together with the literal meaning of the words themselves) the phrase evokes a visceral affect. To think of the horizon the passage now concerns the interlocutors directly. The Ocean River is ever-present. They are immersed in it as they speak. Its extent defines who they are. The Ocean River is consubstantial with the limits of their realm. It has changed dramatically over the course of their lives. Father Mönglik is telling Chinggis Khan, I have been your friend since the time when we were very poor and our world was but nothing to now when our realm has become expansive unto the horizon itself.

Note carefully here the change in modality from one reading to the next. To read the passage in a literal way, the world it represents appears to be objective, intellectual, impersonal, and imaginary. However, to read the passage as allegory, the world it represents appears to be subjective, visceral, personal, and true. And please remember that this change of modality mirrors exactly the change in perception that occurs as we shift from the modern scientific tradition to the pre-modern. In reading the phrase literally we read after the science of the Enlightenment in Europe and the world we live in now. This reading does not conform to the science of the day, however, and, consequently, makes no sense. This passage thus demonstrates something fundament to the humanities: Only

130. De Rachewiltz (2006: 173, 885); Mostaert (1952: 290-292). 
through knowledge of the first principles of science and familiarity with the science of the time can we read in the manner of the sages of yore.

All told, these examples show that not only did the Mongols know the rhetoric of celestial orientation but that it took precedence in their culture. When one studies carefully the allegory of celestial orientation trope by trope, one sees how it thoroughly pervades their rhetoric, governs their lives, and compels them to act as they do.

\section{Astronomy and Technology}

Because they staked their legitimacy as rulers on their affinity with heaven, it was incumbent upon the Mongols to possess superior knowledge of its ways. This meant that they know the rhetoric of heaven, its literature, its use in propaganda, its methods of divination. And it meant too that they possess superior knowledge of astronomy and calendrical science as well.

Though in the early years of the empire the Mongols'knowledge of astronomy paled in comparison with that of their more civilized neighbors, from the time of Chinggis Khan through to the end of the Mongol Empire, the pursuit of stateof-the-art astronomy became a top priority. Indeed the pursuit continued to be a vital aspect of statecraft among their successor states, the Timurids and Mughals. In their unprecedented wealth and influence, the Mongols became exceedingly aggressive patrons of astral sciences. Under Chinggis Khan Yelü Chucai brought Mongolian calendrical science up to the world's standard. Ögedei saw to having a state-of-the-art observatory. ${ }^{131}$ This interest in observatories carried over to his successors. Ögedei's nephew Möngke (r. 1251-1259) hoped to bring in Islamic astronomers to build an observatory at the Mongolian capital, Qaraqorum, but his untimely death forestalled it. ${ }^{132}$ Möngke's younger brother, Hülegü took over Möngke's initiative and charged Nașīr al-Dīn Țūṣī to build the world's finest observatory at Marāgha. ${ }^{133}$ And Möngke and Hülegü's middle brother, Qubilai, furthered the effort by ordering Liu Bingzhong to organize a grand project dedicated to the astral sciences. The project included not only the making of the Shoushili calendar, but the building of observatories in China and the taking of celestial readings from points across the Mongol Empire. ${ }^{134}$ Following the death of Qubilai in 1294 subsequent emperors continued to fund astral sciences. Among the achievements of these latter years was the building of elaborate

131. See Ögedei's biography in the Yuanshi 2.33, 34; see also Wangchug (2008: 142-143).

132. Baumann (2008: 296-297).

133. See Sayili (1960); and Ragep (1993).

134. Sivin (2009; 2005). 
water-clocks. ${ }^{135}$ In the Ilkhanate, among Nașin al-Dīn Ṭūṣ̂̀'s accomplishments, he completed a recension of Ptolemy's Almagest in 1247 and ca. 1250 produced a Persian translation of al-Sufi's Description of the Fixed Stars. ${ }^{136}$ P. Kunitzsch has discovered that when Ulugh Beg made his star catalogue in Samarkand in 1437, he relied upon Nașīr al-Dīn al-Ṭūṣī’s Persian translation of al-Ṣūfī. ${ }^{137}$ As for al-Ṣūī, the Mongols of the Ilkhanate funded multiple editions of his classic work. ${ }^{138}$ These are but a few prominent examples of the Mongols'patronage of astral sciences.

The Mongols did not themselves keep the traditions and technologies through which these achievements were made. Neither did they themselves come up with the innovations or carry out the work that went into them. Rather, they used existing traditions in China and the Islamic world to procure what they desired for themselves just as they relied on existing foreign traditions to procure other things they desired such as textiles, glass, or what have you. In going about achieving their desired end, they did not merely ask the astronomers in their service to carry on as usual. They integrated Chinese and Islamic traditions, reorganized, and revitalized them. ${ }^{139}$ The results were unprecedented in scope and quality. It was in the Mongols'own interest that they ordered these projects be carried out. For these works manifested the Mongols'power and glory. It is wrong to suggest that the Mongol khans sat by passively while to their pleasant surprise their Islamic and Chinese slaves went about aggrandizing them. Decision-making under the Mongols, especially when it concerned important matters of the state, was limited to the family and to a very close circle of Mongols around the khan with the khan himself rendering a final decision, (which was then reified through some form of divination).

\section{Syncretism}

We have seen a number of factors that hide the Mongols' learning. Their knowledge was expressed in esoteric language through allegory. The agency of their decision-making process was blurred by divination and other forms of propaganda. And their priests, sages, and technicians were often foreigners. In addition to these, another factor that hides the Mongols'learning is their syncretism. Syncretism, that is, the keeping as one a mix of multifarious, often

\footnotetext{
135. Needham (1959:313 ff.); Needham et al. (1960: pl. XIII, fig. 51).

136. See Kunitzsch (1989: I, 114, 116).

137. Kunitzsch (1989: I, 115-16; XI, 60-62).

138. See Upton (1933: 180).

139. For a tangible sense of the Mongols'cultural influence, see Komaroff and Carboni (2002); and Komaroff (2006).
} 
contradictory systems, was an intentional approach to learning. It has a basis in nature in that, as nature does not lend itself to a uniform explanation, systems of reflecting natural phenomena are inevitably contradictory. Politically, syncretism was a way to govern far-flung nations whose traditions are diverse. The tradition was known and used in Inner Asia. In Chinese history, where it is spoken of as hunheshuo 混合說 “the doctrine of mixing together," syncretism was an especially prominent feature of governance during the Tang dynasty (618907). The Mongols'predecessors, the Khitans of the Liao dynasty (907-1125, 1124-1211) also relied on syncretism in maintaining indigenous, Buddhist, Chinese, Christian, Islamic, and other traditions within their government. To the West syncretism was used by a host of governments, but the prototype belonged to the Achaemenids (550-330 BC). By compiling in encyclopedic fashion discreet systems, syncretism shows deference to that which is universal. It preserves original sources and lineages of learning. Although syncretism offers its adherents breadth of learning, at the same time it effaces learning, for it leaves a people with little they can claim for their own national heritage. Yet, out of deference to the original, layers to the dissemination of systems peel away like the skin of an onion. ${ }^{140}$

As for the Mongols, their astral tradition is made up almost exclusively of foreign systems. With the founding of the empire in the 13th century, the preBuddhist Mongols adopted the Uygur calendar, which in turn was an adaptation of the Chinese. The trace of Uygur influence on the Mongols is preserved in orthography showing Uygur versions of Middle Chinese. For instance, one Mongolian term for the 9th Heavenly Stem, šim, retains Middle Chinese final $-m$ by way of Uygur šim. ${ }^{141}$

In converting to Buddhism the Mongols adopted the Tibetan Buddhist calendrical tradition. Again in syncretistic fashion, Tibetan Buddhist tradition is comprised of two traditions, Chinese and Indian. ${ }^{142}$ Chinese tradition includes indigenous Chinese systems such as the sexagenary cycle of ten Heavenly Stems (Ch. tiangan 天干) and twelve Earthly Branches (Ch. dizhi 地支), the Chinese Zodiac, the four Sky Animals, and so on. But it also includes Western systems such as the Western Zodiac and the seven day week. These came in varying forms through Indian Buddhism and through Central Asian traditions. The seven day week, for instance, begins on Sunday according to Indian tradition, and on Saturday according to Central Asian tradition. Indian tradition likewise

140. We have discussed the Mongols'syncretism elsewhere (Baumann 2008: 246-251, 276-282).

141. Baumann 2008: 62-63.

142. Baumann 2008: 15, passim. 
has indigenous systems but also is heavily influenced by the West, especially by Greek and Mesopotamian traditions. ${ }^{143}$

The Mongols'sky, so clear and so bright, is filled with foreign stars. What in Mongolian is called na sidar shows the conflation of two distinct systems of asterisms, the Indian nakshatra, from which the Mongolian term derives, and the Chinese xiu 宿. These two systems appear to be organized along the same guiding principles. Both share the same number of asterisms with many of the individual asterisms being either identical or similar. That Central Asian peoples tend to refer to both the Indian and Chinese systems after the Indian nakshatra suggests that the Chinese xiu derive from Indian tradition. But this is far from certain. The Chinese xiu were standardized during the Han dynasty and show little variation over the centuries. The nakshatra on the other hand, used as they were by numerous nations in India and Central and Inner Asia over many centuries, show much variability. Being sometimes 27 but usually 28 in number, the first of them is traditionally and most frequently Krttika (Mong. Kerteg), the Pleiades. The system is sometimes true, that is, defined by the asterisms themselves. Sometimes it is rationalized into numerical degrees. The na sidar asterisms in Mongolian tradition show great variability in terms of the stars comprising the individual asterisms. Between 1683 and 1685 the Tibetan nakshatra were standardized in Gelugpa tradition in the Vaidūrya dkar po "White Beryl" treatise issued under Sang rgyas Rgya mtsho (1653-1705). This standardization is reflected in Gelugpa sources in Mongolian. In 1711 the Chinese xiu along with the rest of the Chinese stars were translated into Mongolian in Tngri-yin udqa [The Way of Heaven], a sophisticated work of Chinese astronomy influenced by Jesuits trained in the Western tradition of Tycho Brahe (1546-1601). This standardization is also frequently followed in Mongolian sources. Apart from these two standardizations, numerous variations on the naysidar can be found in Mongolian sources. These tend to come from heterodox syncretistic sources that preserve (or purport to preserve) the old ways. These systems are similar to Indian sources and the Indian-based Uygur astral tradition of the Yuan time. The orthography of the Mongolian naysidar asterisms changes as much as do the na sidar stars. Still, orthography shows that the Mongolian na sidar system comes to the Mongols from Sanskrit nakshatra through Uygur by way of Tocharian. ${ }^{144}$

143. Baumann 2008: passim.

144. Baumann (2008: 99-114). 


\section{The Rise of Buddhism and the Fall of Heaven}

We conclude our discussion of the power of heaven among the Mongols with an extraneous factor that hides that power from us, namely, their conversion to Buddhism. We have seen the Mongols scorned by their contemporaries as backward. We have seen too how scholars often interpret this backwardness to be a result of their rustic, even primitive, "shamanism." We have tried to demonstrate that the Mongols'culture is by no means as unsophisticated and isolated as it seems. Theirs was an imperial government, an aristocracy endowed with a mandate to rule a world apportioned to them by heaven. They lived under the vault of heaven, patterning their lives and ruling according to its auspices. Their rhetoric was framed as celestial allegory. It reflects symmetry between heaven and earth. In this it is not unlike literature in general. The Mongols rely on their own variations of tropes attested throughout the known world for millennia.

In their rhetoric, in reflecting the times for every purpose, heaven is amoral. It sanctions both good and ill. In ordering the status of men, the Mongols' heaven treats people unequally. It binds them to their lot in life. No two lots are the same. The khan and those close to him possess heaven's share. To change one's lot in life entailed strife. Otherwise, one kept to one's regimen and knew who, from the khan to the lowest slave, followed whom. Among the times for specific purposes, there was a time for war, and theirs was a martial culture. Heaven's auspices were unforgiving and fearsome. They ruled by instilling fear in their subjects. Infamously, in conquering new lands they often resorted to mass executions. The Mongolian seal on Güyük's letter to the Pope reads:

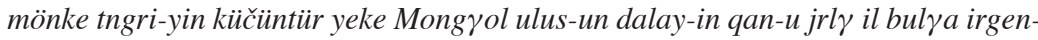

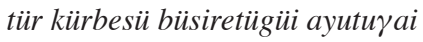

[By the power of eternal heaven, should this edict of the World-wide Khan of the Great Mongol Nation reach any person among the pacified or combatant peoples, let it be heeded; let it be feared! ${ }^{145}$

The Mongols'form of government was not unknown to the known world. Governments of warriors, nomads, and priests typify what has been called the Heroic Era, going back to the Bronze Age, the second millennium BC. ${ }^{146}$ Numerous aspects of the Mongols'government can be found in the governments of their predecessors. In these aspects the Mongols'government follows the model for a World Empire, the prototype for which was established by the Achaemenid Empire.

145. See Kara (2005: 20,157). We have altered his translation modestly.

146. Boyce (1982: 1). 
This form of government came to be threatened by a new form of government, made manifest in a new concept of heaven. This new form of government transcends the empirical reality of heaven with a heaven that exists beyond the lines of separation that apportion time and space. The reality of such a heaven depends on faith. Rather than times for every purpose, heaven is known through an abiding moral order. Rather than that which is evil and imperfect, heaven reflects only that which is good and perfect. Rather than apportioning different lots, everyone receives a full share. Rather than solemnly eternal, a transcendent heaven is characterized by everlasting joy. Under such a heaven, people were known not by their nation but by their faith. To bring this newfound heavenly order to bear on earth, those joined in faith conduct their lives after the heaven that they seek to make manifest. They act in deference to that which is everlasting over that which is transient. They do so out of a sense of morality with kindness and justice for all. And in so doing they set out to create a universal government that will endure in perpetuity regardless of any one person and endure in peace even without an army.

During the formation of this new world order believers spread their propaganda of common humanity against the government of kings and nations calling upon "all the nations" to rise up against the rule of kings. ${ }^{147}$ When these movements first arose, it was enough to leave the coming of the new heavenly order for the future. We find such traditions in the world dominated by the rule of the Achaemenid Empire (550-330 BC), an Aramaic world with influence over, and drawn from, numerous peoples including the Egyptians, Greeks, Indians, and Iranians. We might think of this new world order as "monotheism" but its teachings are expounded in diverse traditions as in the teachings of Zoroastrianism, Judaism, and Plato. During the Hellenistic era (323-31 BC), various movements, including the Buddhist and Christian, set out to bring the newfound heavenly order to bear on earth in the present time. Although we often take Buddhism to have been influenced by the Greeks and Christianity by the Hebrews, in reality the manifold Buddhist and Christian movements were influenced by all of the early traditions, by Zoroastrianism, Judaism, Plato and the Greeks, and more, and influenced by each other as well. Eventually, around the turn of the 7 th $\mathrm{c}$. AD, Islam was born as a continuation of monotheism out of Judaism and Christianity (though Islam too embraced other influences, especially

147. For the monotheistic rhetoric of the end of nations and kings, in addition to the Old and New Testament writings, see also the less familiar apocalyptic literature of the Hellenistic era. In the Book of Enoch (54.1-2) we read, "And I turned and looked to another part of the earth, and saw there a deep valley with burning fire. And they brought the kings and the potentates, and cast them into this deep valley." (Black 1985: 53) 
Indian and Greek traditions and that of the Arabs'own pagan heritage). In China too, along with Buddhism, Confucianism and Daoism emphasized morality and abiding peace and justice over militarism and amoral times for every purpose.

The propaganda for this new world order was a genre of literature dedicated to "salvation." This literature of salvation shares a common heritage among numerous faiths. We find it in Zoroastrianism, Judaism, Platonism, Buddhism, Christianity, Manichaeism, Islam, and more. In this literature, heaven is transformed in a systematic way. In this transformation the tropes that make up the fabric of the heavenly dome are changed to reflect the new world order. It is by changing the makeup of heaven that the government of earth is changed in kind.

In this transformation, it is important to realize that the dome of heaven itself does not disappear, nor are its figures erased. The vault of heaven continues to govern the earth. Its solemn, indifferent nature is merely covered over. For instance, the Ocean Stream figure for the horizon that limits a given realm in the Turkish text of the Manichaean Great Hymn to Mani (ln. 163) is said to be buyanlï taluy ögüz "the Ocean Stream of Meritorious Deeds." ${ }^{148}$ In the Turkish version of the Buddhist Suvarnaprabhāsottamasūtra (V47) the

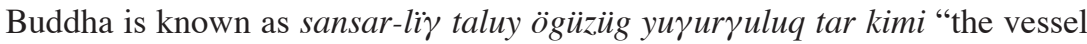
by which one navigates Samsāra's Ocean Stream." ${ }^{149}$ In the same way the heavenly configuration that marks the time when the days become appreciably longer following the winter solstice, a time formerly given to the birth of the likes of Horus, Apollo, and Mithra, in Christian tradition is appropriated for the birth of Jesus Christ. The seasonal nodes and the various stars that mark the four directions, which once had been personified by four warrior kings, come to be personified by the Four Evangelists, common men who conquer the world with nothing but their Good News. ${ }^{150}$

In addition to refashioning the figures of heaven, the heavenly dome itself is transcended by a higher heaven. Beyond the times for every purpose, this higher heaven is given by everlasting moral order. Here no dichotomy exists between good and evil. Only good is to be found. No error or sin is known. Life goes on in joyfulness, and death is no more. In this propaganda heaven and hell are cleft. The sole domain of kings and nobles no longer, heaven's share is

148. SETF II 68-69.

149. Zieme 1996: 194.

150. John in Revelation (4.4-6) cites not the four warrior kings per se but their totems, man, ox, lion, eagle, as taken from Ezekiel 1.4-6. These totems signify nations, as in Daniel (7.2-10) and Enoch (89), the kings of which guard the four directions. For the Four Evangelists as conquerors of the Four Directions in Christian tradition, see Dante's Purgatory (Purg. 29.79-145); Kohler (1923: 2); and Werner (1981). 
apportioned equally to all who would be righteous. No more merely the place of the dead, hell becomes a realm of everlasting punishment for those who sin.

By Chinggis Khan's time the apocalypse of these new forms of government had long since swept across Eurasia, liberating peoples from the confines of heaven's vault. But this change had not come to the Mongols. To speculate on possible reason for this state of affairs, in A History of Zoroastrianism M. Boyce and F. Grenet show that during the Hellenistic era when the transformation of heaven and earth in a new world order was being carried out in the Near East, the Seleucids were defeated by nomadic steppe warriors in eastern Iran. This defeat had the effect of cutting off Central Asia and the Far East from the rapidly changing world of the Near East. ${ }^{151}$ With this break of continuity, the nomadic steppe warriors who came to rule Central Asia, the Sakas (or Scythians), the Yuezhi, and Xiongnu, patterned their governments after the old imperial model. The Mongols followed suit in the manner of the Turks.

It is not that the Mongols did not know of these new-age religions and their teachings. Many Mongols themselves, especially Mongol women, belonged to a particular religious tradition. In the early years of their empire, Syriac-rite Christianity (or Nestorianism) was most prominent among them. However, rather than submitting to any one of these faiths, the Mongols as a people maintained their tradition ultimately as "Mongol." Their destiny belonged to Eternal Heaven and Eternal Heaven alone. ${ }^{152}$ With freedom from Eternal Heaven now commonplace throughout the rest of the world, epithets leveled against the Mongols were made to them as pagan throwbacks. And throwbacks they were, but not - in spite of the rhetoric - simply on account of their being pastoral nomads. The Mongols of Chinggis Khan were throwbacks, just as well, to the likes of Alexander and the Greeks, Cyrus and the Persians, to the Pharaohs of Egypt, and Huangdi in China.

This aloofness from catholic religion ended under the reign of Qubilai Khan (r. 1260-1294) when in 1264 he took up Buddhism for his realm. In particular Qubilai favored the Buddhist schools of the regions of Tibet and especially the Sakyapa Order. In taking up Buddhism, Qubilai formed a union of Church and State. In the process he abrogated the Great Mongol Nation (Yeke Mongrol Ulus) and proclaimed in Chinese tradition, the Yuan dynasty (1271-1368). Reactionaries no longer, the Mongols now liberally championed

151. Boyce and Grenet (1991: 152-155).

152. For the genius of Mongolian tradition as "Mongol" and no other, see the account of William of Rubruck, where in his meetings with Sartaq (d. 1256), Batu (d. 1255) and Möngke (d. 1259), he is assured he must never make the mistake of associating a Mongol with any religion other than "Mongol" (Dawson 1955: passim). See also Juvaini (1958: 26). 
the most progressive government the world had known to date. Their legacy would continue to influence statecraft for centuries to come as world empires combining a dual regency of Church and State became the norm for governments across Eurasia. ${ }^{153}$

No matter how necessary Qubilai's actions may have been, his transformation of the Mongolian government was not universally accepted by the members of his family. Upon his ascension to the throne civil broke out. In the propaganda of the Mongols'civil war, Qubilai's enemies consistently accuse him of betraying Mongol tradition. Scholars often cynically write off the Mongols'ideological rhetoric as a pretense to more base grudges over power and wealth. ${ }^{154}$ These cynical dismissals make for one of the greatest red herrings in all of World History, for they overlook the means by which this profoundly consequential transformation took place.

Accepting Buddhism meant the end of the Mongol Empire as Chinggis Khan had forged it. Buddhist dharma flies directly in the face of everything he stood for. Its literature of salvation transforms the Mongols'government first and foremost by transcending and transforming the allegory of the vault of heaven. We see an example of this transformation in a pre-classical verse treatise on salvation, Oyin-i geyigülüggči neretü šastir [Illumination of the Mind Treatise], where we read:

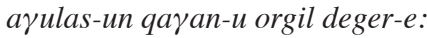

amuүulang-du töröl-tür töröjü:

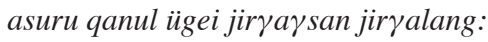

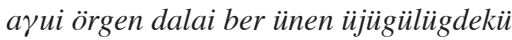

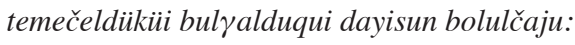

terigüben esergü tesergü čabčilaldu $\gamma$ san:

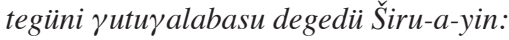

tere yirtinčü-deče marad aldaraqu::

On the summit of the king of mountains

Being born to a life of quietude

Pleasures enjoyed greatly without surfeit

Unto a vast wide ocean should be seen.

[But] struggling vying enemies conflict

Tit for tat hacking off each other's heads

153. For the spread of Buddhism among the Mongols and Qubilai Khan's conversion, see Heissig (1980: 24-25).

154. Robinson (2009: 17). 
And when so they dishonor themselves

All is lost from the supreme Zurvan's world. ${ }^{155}$

The king of mountains here refers a heavenly mountain, the mountain by which order is created over chaos, the mountain that reaches from the center of government to the celestial pole, the North Pole for peoples living in the Northern Hemisphere. There ought to be but one such mountain in the world,

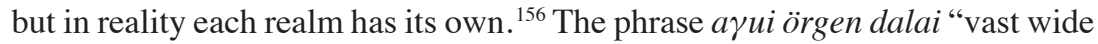
ocean" refers to the World Ocean, a metaphor for the horizon that circles the world from a given point of observation, and so means "to the ends of the earth." It was the goal of any great hero who would be king to reach the summit of this mountain and pacify the world. Chinggis Khan climbs higher up this mountain than any other man before or since. Yet Buddhist soteriology repudiates the entire endeavor as folly. In another faction of the greater movement, we find the same transcendence of the old trope in Christian tradition where the Tempter, Satan, magically transports Jesus to the peak of a different version of this same mountain. Here (Mt. 4.8-10) Satan shows Jesus all the kingdoms of the world and the glory of them. "All these I will give you, if you will fall down and worship me," he says. Jesus sees the illusion for what it is and sends the Devil away. But Chinggis Khan has taken this vision as his charge to rule the world.

In this contrast of views we see the radical change Buddhism brought to the Mongols. The literature of Buddhist soteriology opposed the government of the Mongol Empire in every way imaginable. It opposed their militaristic order, their hoarding economic system, their fine clothing and sumptuous food, their marriage and death rites, their hunting rituals, their bloody sacrifices, and on and on. From the outset Mongolian traditions were altered by Buddhism. Over time the allegory of the power of heaven was eroded away. After the fall of the empire the Dalay-yin qan was replaced by the Dalai Lama. Eventually, under Communism the rhetoric of "the power of eternal heaven" was all but forgotten, so that now all that is left of the Mongols'ancient government is the eternal sky itself.

\section{Works Cited}

[AL-BIRUNI] Muhamad ibn Ahmad Biruni (1879). Chronology of Ancient Nations an English version of the Arabic Text of the Athar-ul-Bakiya of Albiruni or 'Vestiges

155. Lokesh Chandra (1982: 438).

156. See the term taylar xan "King of the Montains" in reference to the Old Turkic epithet of Mt. Meru in Röhrborn (1971: 18 ln. 32). 
of the Past' Collected and Reduced to Writing by the Author in A.H. 390-1, A.D. 1000. Edward Sachau, transl. London: William H. Allen and Co.

AL-KĀSHGHARĪ, Mạ̣mūd (1985). Compendium of the Turkic Dialects (Dīwān Lưāt atTurk). 2 vols. Robert Dankoff and James Kelly, eds. and transls. Boston: Harvard University.

Allen, Richard Hinckley (repr. 1963). Star Names: Their Lore and Meaning. New York: Dover Publications.

Allsen, Thomas T. (2006). The Royal Hunt in Eurasian History. Philadelphia: University of Pennsylvania Press.

Amitai-Preiss, Reuven (1991). "Evidence for the Early Use of the Title Ilkhan among the Mongols." Journal of the Royal Asiatic Society of Great Britain \& Ireland, 1: 353-361.

Aratus (1997). Phaenomena. Douglas Kidd, ed. and transl. Cambridge: Cambridge University Press.

Barker, Peter and Ariew, Roger, eds. (1991). Revolution and Continuity. Washington D.C.: Catholic University of America Press.

Battenhouse, Roy W. (1941). "Tamburlaine, the 'Scourge of God'." Publications of the Modern Language Association (PMLA), 56: 337-348.

Baumann, Brian (2008). Divine Knowledge: Buddhist Mathematics according to the Anonymous Manual of Astrology and Divination. Leiden: Brill, 2008.

BAzIN, Louis (1991). Les Systèmes chronolgiques dans le monde Turc ancien. Budapest: Akadémiai Kiadó.

Beal, Samuel (repr. 1970). A Catena of Buddhist Scriptures from the Chinese. Taipei: Ch'eng Wen.

Beffa, M.-L. (1993). "Le concept de tänggäri, 'ciel', dans l'Histoire secrète des Mongols." Études mongoles et sibériennes, 24: 215-236.

Berggren, J. Lennart and Jones, Alexander (2000). Ptolemy's Geography: an Annotated Translation of the Theoretical Chapters. Princeton: Princeton University Press.

Bernstein, Alan E. (1996). The Formation of Hell: Death and Retribution in the Ancient and Early Christian Worlds. Ithaca: Cornell University Press.

[BнP] (1970). The Bhāgavata-Purāna. Ganesh Vasudeo Tagare, transl. V Parts. Ancient Indian Traditions and Mythology. Vols. 7-11. Delhi: Motilal Banarsidass.

BIRA, Sh. (2004). "Mongolian Tenggerism and Modern Globalism." Journal of the Royal Asiatic Society, 14: 3-12.

Biran, Michal (1997). Qaidu and the Rise of the Independent Mongol State in Central Asia. Surrey: Curzon.

Black, Matthew (1985). The Book of Enoch or I Enoch. Leiden: E. J. Brill.

Boyce, Mary (1989). A History of Zoroastrianism. Volume I: The Early Period, Leiden: E. J. Brill.

Boyce, Mary (1982). A History of Zoroastrianism. Volume II: Under the Achaemenians. Leiden: E. J. Brill.

Boyce, Mary and Grenet, Frantz (1991). A history of Zoroastrianism. Volume Three: Zoroastrianism under Macedonian and Roman Rule. Leiden: E. J. Brill.

Boyle, J. A. (1977). The Mongol World Empire, London: Variorum Reprints. 
Buell, Paul (2008). Review of Thomas Allsen's The Royal Hunt in Eurasia History (Philadelphia: University of Pennsylvania Press, 2006). In Mongolian Studies, 30: 83-85.

Burgess, Ebenezer (1860). "Translation of the Sūrya-Siddhānta, a Textbook of Hindu Astronomy; with Notes, and an Appendix by Rev. Ebenezer Burgess." JAOS: 141-499.

Carroll, Lewis (1946). Alice in Wonderland and Through the Looking Glass. New York: Grosset \& Dunlap.

Clagett, Marshall (1989). Ancient Egyptian Science. 3 vols., Philadelphia: American Philosophical Society.

Clauson, Gerard (1964). "Early Turkish Astronomical Terms." Ural-Altaische Jahrbücher, 35: 350-368.

Clauson, Gerard (1972). An Etymological Dictionary of Pre-Thirteenth-Century Turkish. Oxford: Clarendon.

Corbin, Henry (1960). Avicenna and the Visionary Recital. W. R. Trask, transl. New York: Bollingen Foundation.

DARMeSteter, James, transl. (repr. 1974). The Zend-Avesta. Part I, The Vendīdad. Delhi: Motilal Banarsidass.

Darmesteter, James, transl. (repr. 1975). The Zend-Avesta. Part II, The Sīrōzahs, Yasts and Nyāyis. Delhi: Motilal Banarsidass.

Dawson, Christopher, ed. (1955). The Mongol Mission: Narratives and Letters of the Franciscan Missionaries in Mongolia and China in the Thirteenth and Fourteenth Centuries. A nun of Stanbrook Abbey, transl., New York: Sheed and Ward.

[DDD] (1995). Dictionary of Deities and Demons in the Bible. Karel van der Toorn, Bob Becking, Pieter W. van der Horst, eds. Leiden: E.J. Brill.

Di Cosmo, Nicola, Frank, Allen J. and Golden, Peter B., eds. (2009). The Cambridge History of Inner Asia. Cambridge: Cambridge University Press.

DoERFER, Gerhard $(1963,1965)$. Türkische und mongolische Elemente im Neupersischen . 2 vols. Wiesbaden: Franz Steiner Verlag.

Eliade, Mircea (1964). Shamanism: Archaic Techniques of Ecstasy. New York: Pantheon Books.

EnO, Robert (1996). "Deities and Ancestors in Early Oracle Inscriptions." Religions of China in Practice. Donald S. Lopez, ed. Princeton: Princeton University Press, 41-51.

Fletcher, J. (1986). “The Mongols: Ecological and Social Perspectives.” HJAS, 46: 11-50.

Geus, Klaus (2011). Review of Duane W. Roller, transl., Eratosthenes'Geography, Princeton: Princeton University Press. Isis, 102: 554.

GinZEL, F. K. (1906). Handbuch der mathematischen und technischen Chronologie. 2 vols. Leipzig: J. C. Hinrichs'Buchhandlung.

Golden, Peter B. (2009). Review of David Sneath, The Headless State: Aristocratic Orders, Kinship Society, and Misrepresentations of Nomadic Inner Asia. In The Journal of Asian Studies, 68: 293-296.

Golden, Peter B. (2010). Journal of Asian Studies 69: 660-663. 
DE Gubernatis, Angelo (repr. 1978). Zoological Mythology. 2 vols. New York: Arno Press.

HaEnisch, Erich (1957). Sinomongolische Glossare. I. Das Hua-I ih-yü. Berlin: Akademie-Verlag.

HALPERIN, Charles (2000). "The Kipchak Connection: The Ilkhans, the Mamluks and Ayn Jalut.” BSOAS, 63: 229-245.

Heissig, Walther (1980). The Religions of Mongolia. G. Samuel, trans. Berkeley: University of California Press.

Hunger, Hermann and Pingree, David (1999). Astral Sciences in Mesopotamia. Leiden: Brill.

JACKSON, Peter (2006). "World-Conquest and Local Accomodation: Threat and Blandishment in Mongol Diplomacy." History and Historiography of PostMongol Central Asia and the Midddle East: Studies in Honor of John E. Woods. Judith Pfeiffer and Sholeh A. Quinn, eds. Wiesbaden: Otto Harrassowitz, 3-22.

Jones, J. J., transl. (1949). The Mahāvastu. Vol. 1. London: Luzac and Co., Ltd.

JuvainI, Ata-Malik (1958). The History of the World-Conqueror. 2 vols. J.A. Boyle, transl. Manchester: Manchester University Press.

KARA, György (1990). "Zhiyuan yiyu index alphabétique des mots mongols." Acta Orientalia Hungarica, 44: 279-344.

KARA, György (2005). Books of the Mongolian Nomads: More than Eight Centuries of Writing Mongolian. Bloomington: Research Institute for Inner Asian Studies.

Keith, Arthur Berriedale, transl. (repr. 1981). Rigveda Brahmanas: The Aitareya and Kausittaki Brāhmanas of the Rigveda. Delhi, Motlilal Banarsidass.

Knopfler, Mark (1985). "Brothers in Arms." Brothers in Arms. New York: Warner Bros. CD.

KoHLER, Kaufmann (1923). Heaven and Hell in Comparative Religion: With Special Reference to Dante's Divine Comedy. New York: Macmillan Co.

Komaroff, Linda, ed. (2006). Beyond the Legacy of Genghis Khan. Leiden: Brill.

Komaroff, Linda and CArboni, Stefano (2002). The Legacy of Genghis Khan: Courtly Art and Culture in Western Asia, 1256-1353. New York: The Metropolitan Museum of Art.

Kunn, Thomas S. (1957). The Copernican Revolution: Planetary Astronomy in the Development of Western Thought. Cambridge: Harvard University Press.

Kunitzsch, Paul (1961). Untersuchungen zur Sternnomenklatur der Araber. Wiesbaden: Otto Harrassowitz.

Kunitzsch, Paul (1989). The Arabs and the Stars: Texts and Traditions of the Fixed Stars, and their Influence in Medieval Europe. Northampton: Variorum Reprints.

Legge, James (repr. 1985). The Chinese Classics. IV The She King. Taipei: Southern Materials Center.

Ligeti, Louis (1990). "Un vocabulaire Sino-Mongol des Yuan le Tche-yuan yi-yu.” Acta Orientalia Hungarica, 44: 259-277.

LoKesh Chandra (1982). Early Buddhist Texts in Mongolian. 2 vols. New Delhi.

[MNTSD] (1999). Mongol nutag dakh'tüïkh soyolyn dursgal [Historical and Cultural Monuments in Mongolia]. Ulaanbaatar: Mongolian Academy of Humanities. 
MolnáR, Ádám (1994). Weather-magic in Inner Asia. Bloomington: Research Institute for Inner Asian Studies.

Mostaert, Antoine (1952). "Sur quelques passages de l'Histoire secrète des Mongols." HJAS, 15: 285-404.

Mostaert, Antoine (1962). “À propos d'une prière au feu,” in American studies in Altaic Linguistics, Nicholas Poppe, ed., Bloomington: Indiana University, 191223.

Mostaert, Antoine and Cleaves, Francis Woodman (1962). Les Lettres de 1289 et 1305 des ilkhan Aryun et Öljeitü à Philippe le Bel. Scripta Mongolica Monograph Series I. Cambridge: Harvard-Yenching Institute.

Needham, Joseph (1959). "The Science of the Heavens." Science and Civilization in China. vol. 3. Cambridge: Cambridge University Press.

Needham, Joseph, Wang Ling and DE Solla Price, Derek J. (1960). Heavenly Clockwork: the Great Astronomical Clocks of Medieval China, Cambridge: Cambridge University Press.

Neugebauer, O. (1968). Exact Science in Antiquity. Copenhagen: Ejnar Munksgaard.

Neugebauer, O. and Parker, Richard A. (1960). Egyptian Astronomical Texts. 3 vols. Providence: Brown University Press.

[OED] (1989). The Oxford English Dictionary. $2^{\text {nd }}$ ed. Oxford: Oxford University Press. Olbricht, Peter and PINKs, Elisabeth, transl. (1980). Meng-ta pei-lu und Hei-ta shihlüeh: Chinesische Gesandtenberichte über die Frühen Mongolen 1221 und 1237. [Chao Kung]. Wiesbaden: Otto Harrassowitz.

Olschki, Leonard (1949). The Myth of Felt, Berkeley: University of California Press.

Pedersen, Morten A. (2001). "Totemism, Animism and North Asian Indigenous Ontologies." The Journal of the Royal Anthropological Institute, 7: 411-427.

Plutarch (1936). Moralia V: Isis and Osiris. The E at Delphi. The Oracles at Delphi.

The Obsolescence of Oracles. Frank Cole Babbitt, transl. Cambridge: Harvard University Press.

Poppe, N. (1925). “Zum Feuerkultus bei den Mongolen,” Asia Major, 2: 130-145.

Pritchard, James B., ed. (1969). Ancient Near Eastern Texts Relating to the Old Testament. $3^{\text {rd }}$ ed. Princeton: Princeton University Press.

Pritchard, James B. (1954). The Ancient Near East in Pictures Relating to the Old Testament. Princeton: Princeton University Press.

DE RACHEWILTZ, Igor (1972). Index to the Secret History of the Mongols. Bloomington: Indiana University.

DE Rachewiltz, Igor et al., eds. (1993). In the Service of the Khan Wiesbaden: Harrassowitz Verlag.

DE Rachewiltz, Igor, transl. (2006). The Secret History of the Mongols: A Mongolian Epic Chronicle of the Thirteenth Century. Leiden: Brill.

DE RACHEwILTz, Igor (2007). "Heaven, Earth and the Mongols in the Time of Činggis Qan and his Immediate Successors (ca. 1160-1260) - a Preliminary Investigation." A Lifelong Dedication to the China Mission: Essays Presented in Honor of Father Jeroom Heyndrickx, CICM, on the Occasion of His 75th Birthday and the 25th 
Anniversary of the F. Verbiest Institute K.U.Leuven. Noël Golvers and Sara Lievens, eds. Leuven: Fedinand Verbiest Institute.

RAGEP, F. J. (1993). Nas̄̄r al-Dīn al-Tūsī's Memoir on Astronomy (al-Tadhkira fì 'ilm al-hay'a). 2 vols. New York: Springer-Verlag.

Rackham, H., transl. (1949). Natural History. [Pliny]. Vol. 1. Cambridge: Harvard University Press.

Ratchnevsky, Paul (1970). "Über den mongolischen Kult am Hofe der Grosskhane in China.” Mongolian Studies. Louis Ligeti, ed. Amsterdam: B. R. Grüner, 417-443.

Robinson, David M. (2009). Empire's Twilight: Northeast Asia under the Mongols. Cambridge: Harvard University Press.

RockHILl, William Woodville, transl. (1900). The Journey of William of Rubruck to the Eastern Parts of the World, 1253-55, as Narrated by Himself, with two Accounts of the Earlier Journey of John of Pian de Carpine. London: The Hakluyt Society.

RöHrborn, Klaus (1971). Eine uigurishe Totenmesse. Berlin: Akademie-Verlag.

Roller, Duane W., transl. (2009). Eratosthenes'Geography. Princeton: Princeton University Press.

SaCHAU, Edward, transl., (1879). Chronology of Ancient Nations an English version of the Arabic Text of the Athar-ul-Bakiya of Albiruni or 'Vestiges of the Past' Collected and Reduced to Writing by the Author in A.H. 390-1, A.D. 1000. [Muhamad ibn Ahmad Biruni (al-Bīrūnī)]. London: William H. Allen and Co.

SALIBA, George (2006). "Horoscopes and planetary theory: Ilkhanid patronage of astronomers." Beyond the Legacy of Genghis Khan. Linda Komaroff, ed. Leiden: Brill, 357-368.

SAYILI, Aydin (1960). The Observatory in Islam and its Place in the General History of the Observatory. Ankara: Türk Tarih Kurumu Basimevi.

SEla, Ron (2003). Ritual and Authority in Central Asia: the Khan's Inauguration Ceremony. Papers on Inner Asia, v. 37. Bloomington: Research Institute for Inner Asian Studies, Indiana University.

[SETF] (1972). Sprachwissenschaftliche Ergebnisse der deutschen Turfan-Forschung. Albert August von Le Coq, F. W. K. Müller, Willi Bang, Annemarie von Gabain, Gabdul Rashid Rachmati, Wilhelm Thomsen, eds. 2 vols. Leipzig: DDR.

SINor, Denis (1972). "The Mysterious 'Talu Sea' in Öljeitï's Letter to Philip the Fair of France." Analecta Mongolica. John G. Hangin and Urgunge Onon, eds. Occasional Papers 8. Bloomington: The Mongolia Society, 115-121.

Sivin, Nathan (2005). "A Multi-dimensional Approach to Research on Ancient Science." East Asian Science, Technology, and Medicine, 23: 10-25.

Sivin, Nathan (2009). Granting the Season: The Chinese Astronomical Reform of 1280, With a Study of Its Many Dimensions and an Annotated Translation of Its Records. New York: Springer.

SneAth, David (2007). The Headless State: Aristocratic Orders, Kinship Society, \& Misrepresentations of Nomadic Inner Asia. New York: Columbia University Press.

SneAth, David (2010). The Journal of Asian Studies, 69: 658-660.

Su Tianjue (1962). Yuan chao ming chen shi lue. Beijing: Zhonghua shu ju ying yin. 
Tekin, Talat (1968). A Grammar of Orkhon Turkic. Bloomington: Indiana University. Tekin, Talat (1993). The Irk Bitig. The Book of Omens. Wiesbaden: Harrassowitz Verlag. Thackston, W.M., transl. (1998). Rashiduddin Fazlullah's Jami'u't-tawarikh: Compendium of Chronicles: a History of the Mongols. 3 vols. Cambridge: Harvard University.

Titzherbert, Teresa (2006). "Reilgious diversity under Iklhanid rule c. 1300 as reflected in the Freer Bal'ami." Beyond the Legacy of Genghis Khan. Linda Komaroff, ed. Leiden: Brill, 390-406.

TurAn, Osman (1955). "The Ideal of World Domination among the Medieval Turks." Studia Islamica, 4: 77-90.

Utz, David A. (1998). "A Sogdian Thaumaturgical Text from Dunhuang and the Origins of Inner Asian Weather Magic." Historical Themes and Current Change in Central and Inner Asia. Michael Gervers and Wayne Schlepp, eds. Toronto: Toronto Studies in Central and Inner Asia, 101-121.

Vahman, Fereydun (1986). Ardā Wirāz Nāmag: The Iranian 'Divina Commedia'. London: Curzon Press.

Waley, Arthur (repr. 1979). The Travels of an Alchemist. The Journey of the Taoist Ch'ang-Ch'un from Chinato the Hindukush at the Summons of Chingiz Khan Recorded by his Disciple Li Chih-ch'ang. London: George Routledge \& Sons.

WANGCHUGH, B. (2008). Monggholchud-un sinjilekü uqaghan teknig-ün teüke: odun oron jiruqai-yin uqaghan [History of the science and technology of the Mongols: astral sciences]. Kökeqota: Öber Mongghol-un arad-un keblel-ün qoriy-a.

Werner, Martin (1981). "The Durrow Four Evangelist Symbols Page Once Again." Gesta, 20: 23-33.

Whiston, William (1755). A new theory of the earth, from its original to the consummation of all things. Wherein The Creation of the World in Six Days, The Universal Deluge, And the General Conflagration, as laid down in the Holy Scriptures, Are shewn to be perfectly agreeable to Reason and Philosophy. 6th ed., London.

Yuanshi (1976). Song Lian et al., ed. Beijing: Zhonghua Shuju.

Yule, Henry, transl. (1929). The Book of Ser Marco Polo the Venetian Concerning the Kingdoms and Marvels of the East. 2 vols. London: John Murray.

ZIEME, Peter (1996). Altun Yaruq Sudur, Vorworte und das erste Buch: Edition und Übersetzung der alttürkischen Version des goldglanzsūtra (Suvarnaprabhāsottamasūtra). Berliner Turfantexte XVIII. Turnhout: Brepols. 